\title{
Sangmotivets funktion i to tekstrettelser hos Grundtvig
}

\author{
Af Aage Schiøler
}

Med afsæt i tre karakteristiske eksempler på Grundtvigs brug af sangmotivet til at angive et indgreb og en vending i menneskets eksistens fra den for ham eksterne instans, han benævner Gud, og til at markere indgrebets indhold, undersøges baggrunden for to karakteristiske ændringer blandt de mange, Grundtvig foretog ved genudgivelse af egne skrifter. Undersøgelsen samler sig om sammenhængen mellem på den ene side tidspunktet for og anledningen til genudgivelsen og på den anden side sangmotivets funktion i den forbindelse. Hensynet til tekstens brug i offentligheden fremtræder derved som medvirkende årsag til ændringerne.

\section{Sangen som markør af en vending i tre Grundtvig-tekster}

Til belysning af bredden i Grundtvigs brug af sangmotivet i beskrivelser af en nyorientering gennemgås i kronologisk rækkefølge tre salmer. De tre salmers udgangspunkter er tre forskellige fænomener fra menneskets livsverden, de har tilknytning til hver sin af dåbsbekendelsens tre artikler, og de er blevet til i hver sin periode af hans salmeproduktion. På den baggrund vurderes de som repræsentative til belysning af emnet. Alle tre er de eksempler på, at englenes og menneskets sang bruges som værktøj i forbindelse med, at det nye indtræffer, og der iværksættes en vending i den læsende/syngende persons eller forsamlings situation. Derudover viser de, at sangen også fungerer som bærer af den glæde, der er vendingens stadige følge og korrelat.

\section{Tekstgennemgange}

\section{Inkarnationens under}

I "Et Barn er født i Bethlehem", 1820 (GSV II, 194-95), opfordres vi i str. 1-2 til at glæde os over, at et barn er kommet til verden, selv om det er sket $\mathrm{i}$ beskedne kår uden for offentlighedens opmærksomhed. Først bagefter fortælles det, at barnet er "Himlens Kongesøn". I str. 910 er den rent menneskelige glæde blevet til en sammensmeltning af den jordiske og den himmelske glæde.

Salmens vendepunkt er oprettelsen af et nyt eksistensvilkår for mennesker: "Guds kicere Børn vi blev paa Nye" (min kursivering), fordi "al vor Nød" ved dette barns fødsel er "forvunden", besejret, selv om den ikke er forsvundet, er ude af verden (str. 5-6). 
Ved den første mellemstation, str. 3-4, møder vi i salmeforløbets fortid de vise mænds vandring og ser dem bringe gaver (Matt 2,1-12), og vi hører Guds engle synge (Luk 2,14). Ved den anden mellemstation, str. 7-8, deltager vi i vores egen nutid som kirkegængerne i hyldesten til barnet. "Stjerne-Tepper lyseblaae" viser vores ligestilling med de vise mænd fra Østerland som i "Deilig er den Himmel blaa" (GSV II, str. 1, 197), og det siges ligeud, at vi lærer at synge som englene julenat.

Englesangen er her et hjælpemiddel, der rækkes mennesker, så de dels kan udtrykke deres glæde over, at "Os er i Dag en Frelser fød!" (str. 5), dels medvirke til udbredelsen af nyheden herom, julens evangelium. Englesangen julenat i Luk 2,14, viderebringer på tilsvarende vis budskabet i Luk 2,10. Hyrderne gør det i 2,17.20. ${ }^{1}$

\section{Den livgivende And}

"Du som gaaer ud fra den levende Gud", 1837 (GSV I, 625-627), er en bøn til Helligånden. I str. 1 er bønnen et angstfyldt råb, udsprunget af modsætningsforholdet mellem mennesker og Gud. Råbet lyder på baggrund af den gamle metafor: mørket som Guds modstander, mennesket er magtesløst over for, og lyder:

Men af din Naade, o bliv dog her!

Natten er skummel og den er nær!

(GSV I, str. 1, 626)

Heroverfor står i str. 6 den forventningsfulde og tillidsbårne bøn om "Saligheds Fryd" for ethvert menneske. Bønnen hviler nu på udkommet af Jesu skæbne, "Gienløserens Dyd", der karakteristisk for Grundtvigs dynamiske treenighedstænkning ses som et samvirke i guddommens tre aspekter:

Faderens Raad og den Hellig-Aands Daad

Sammen i Frelseren falde!

(GSV I, str. 6, 627)

At den forløsning, Gud foranlediger, sker i frihed, ikke med tvang, markeres med grænsebegrebet "Fortabelsens Æt" i samme strofe.

Omsvingets forudsætning føres ind i menneskets dagligdag, "komme tilbyes", gennem den opmuntring til glæde, trøst og hjælpsomhed, de, der lægger stemme til "Evangeliets milde Røst", bringer med sig (str. 3). Omsvingets følger bæres også her af sangen (str. 4). $\mathrm{Nu}$ er den integreret i det milde og venlige vejrlig, der kan være en livsbekræftende erfaring for mennesker på vore breddegrader en forsommermorgen. Dens fornyende funktion fremgår af linjerne: 
Tonerne dybe i Gry og Kveld

Røre selv Hjertet saa haardt som Fjeld!

(GSV I, str. 4, 626)

Kirkeklokkernes morgen- og aftenringning i den lyse Maj måned er en parallel til julemorgens julens kimen til kirke i "Velkommen igien, Guds Engle smaa", 1825 (GSV I, str. 6, 406), og de "Høiere (...) stemte (...) Toner" "i Paaske-Morgengry" i "Kirke-Klokke! Mellem ædle Malme", 1845 (GSV IV, str. 5, 189).

Gennemgangsleddet forud for omsvinget er forkyndernes færden med evangeliet ud til alle jordens folkeslag uden undtagelse (GSV I, str. 2, 626). Det tilsvarende led efter omsvinget er den stadige viderebringelse af menighedens tilblivelsesfortælling båret af dåb, forkyndelse og nadver (str. 5).

Som redskab til at give udtryk for overbevisningen om den treenige Guds genløsergerning som nutidig, nydannende virksomhed bruger salmen altså det for danskere fortrolige forsommerfænomen, der efter vintertidens mørke på ny giver glæde ved livet, lyst til at tage fat og tilskyndelse til taknemmelighed. Den lydlige side, "Tonerne dybe i Gry og Kveld", svarer ganske til englenes sang i "Et Barn er født i Bethlehem". Forholdet mellem impuls i str. 3 over for reaktion i str. 4 er af samme art som i skiftet fra str. 3-4 til str. 7-8 i julesalmen. ${ }^{2}$

\section{Skabervarkets sprogkraft}

I “Alt hvad som Fuglevinger fik", 1851 (GSV IV, 290-291), transformeres sangevnen, som vi har tilfælles med fuglene, og som i salmens verden hos begge parter bruges til at udtrykke taknemmelighed for alt godt i denne tilværelse (str. 1). Det sker på en måde, så den overgår både fuglenes sang, den mest umiddelbare her på jorden, og englenes "livsalige" sang i Himlen og lyder "til evig Tid" (str. 6).

Vendepunktet er str. 3, der fortæller, at Guds nåde ved Jesu komme opsøger mennesket, det væsen af alle, der har hårdest brug for den. I denne strofe er "Trang" ikke en ubestemt, retningsløs længselsfølelse. Glosen har fra gammel tid betydningen af det, vi nødvendigvis har brug for, trænger til, også selv om vi måske ikke har opdaget det, som i Kingos "Du bedst min Tarv og Trang / O Herre kiender" (KSS III, str. 9, 85. Flere eksempler i $H B, 505-506)$. "Du trænger til frisk luft. Hent et franskbrød hos fru Møller i hjemmebageriet", kunne det også omkring 1945 lyde til læsehesten, der en sommerdag med gråvejr var forsvundet op i Kashmirs bjerge sammen med Kiplings Kim og Teshoo Lama.

I mellemleddene møder vi i str. 2 opfordringen til almindelig, daglig brug af sangevnen, fordi den er vores mest frigørende evne og tildeler os det størst mulige livsrum. Den tilsvarende opfordring i str. 4 
gælder takkesangen til den Gud, vi er døbt til: Skaberen, Genløseren, Trøsteren. Nu er godheden intensiveret fra, at Guds nåde "raader Bod" (str. 1), til, at Gud i den "over os sin Kiærlighed / (...) udøser". Fra at få repareret en skade bliver vi inddraget i en sublim godhed. Der skal jo i øvrigt allerede i det jordiske perspektiv foruden jod og plaster på såret også milde ord, et smil, et pust på det sted, der gør ondt og gerne tillige et klap på kinden eller et lille knus til, for at barnet, der har skrammet sit knæ under leg ude i gården eller på gaden, føler sig helt hjemme igen. For slet ikke at tale om de tilfælde, hvor skaden ikke på nogen måde lader sig genoprette, men hjemligheden uanset hvad dog skal opretholdes, for at menneskeligheden kan bevares, og 'ord, som forløser' er eneste adgangsvej hertil.

Ved salmens slutning tales der om den nære Gud i menighedens gudstjeneste, det være sig som fuld højmesse i kirken eller som morgen- eller aftensang hjemme med børnene, ikke om en fjern Gud, der står bagved verdensaltets endeløse dybder og beundringsværdige detaljer. Derfor kan vi bruge en af disse detaljer, sangevnen, som det selvfølgelige middel til at udtrykke vores afhængighed af, vores tillid til og vores taknemmelighed og glæde over for den Gud, der er gået ind i vores eksistens som Genløser med sin grænseløse godhed. Vores sang er blevet "Engle-Sang".

\section{Virkekraften i vendingen}

Godheden andetsteds fra, der foranlediger vendingen i salmerne, lader sig gennem to prægnante passager fra $N T$ beskrive på en måde, så det er relevant i sammenhængen. Den ene er 1 Kor 13, kaldet "Højsang til Kærligheden", med det kendte klimaks i v. 13: "Så bliver da tro, håb, kærlighed, disse tre. Men størst af dem er kærligheden". Den anden passage er 1 Joh 4,7-21, med centrum i v. 16b: "Gud er kærlighed, og den, der bliver i kærligheden, bliver i Gud, og Gud bliver i ham".

Begge steder fremgår det af sammenhængen, at den kærlighed, der tales om, har afsløret sig i Jesus fra Nazareth gennem hans udsagn og handlinger, hans liv og hans skæbne. I Joh er det den helt nære sammenhæng, idet v. 9 lyder: "Derved er Guds kærlighed blevet åbenbaret iblandt os: at Gud har sendt sin enbårne søn til verden, for at vi skal leve ved ham". I 1 Kor er det den videst mulige sammenhæng, indledt i 1,21-33: "vi prædiker Kristus som korsfæstet, (...) som Guds kraft og Guds visdom", og afsluttet i kap. 15 om Kristi Opstandelses implikationer ved vores inddragelse $\mathrm{i}$ hans totaleksistens, kort udtrykt $\mathrm{i}$ v. 49b: "således skal vi også bære den himmelskes billede".

Selv om denne godhed andetsteds fra i de tre salmer finder sit udtryk gennem omtale af almenmenneskelige erfaringer: barnefødslen, forsommeren og sangevnen, er der altså ingen grund til at afskrive 
dens gamle betegnelse: Guds kærlighed i Kristus Jesus, vor Herre. ${ }^{4}$ Samtidig viser passagen 1 Kor 10,1-13, om Israel i ørkenen og henvisningen til Kain i 1 Joh 3,12, at der er tale om den Gud, jødefolket på Jesu tid dyrkede i templet, tilbad i synagogerne og læste om hos "Moses og profeterne" (Luk 16,29.31), og at kærligheden henvender sig til "utaknemmelige og onde" (Luk 6,35).

\section{Sammenfatning}

Alle tre salmer giver udtryk for en ændring i den menneskelige tilværelses vilkår. Omsvinget er i dem alle knyttet til det indbrud fra den gode os til gode, inkarnationen for kristentroen markerer i menneskeslægtens forhold. I "Et Barn er født (...)" er det beskrevet med omtalen af, at den nyfødte er "Himlens Kongesøn". I "Du som gaaer ud (...)" gennem nævnelsen af "Gienløserens Dyd". I "Alt hvad som Fuglevinger fik" med ordene om, at nåden kom "med Vorherre", dvs. med Jesus fra Nazareth set som Guds Søn.

Hver for sig bruger salmerne et kendt erfaringsgrundlag: barnefødslen, forsommeren, sangevnen, til at udtrykke denne ændring, skønt den i sin grund ikke er noget, vi kan sige os selv. Erfaringsgrundlagets forskellige sproglige udtryk gennemgår alligevel i digterens hænder en transformation, så de bringes til at udsige den godhed andetsteds fra, der i hans optik er mennesketilværelsens yderste instans. Derved overbydes "Al vor Nød" af børnekår hos Gud, modviljen mod Gud af "Saligheds Fryd" og nødvendigheden af Guds nådes nærvær.

Da selve sangen i de tre salmer på hver sin måde er knyttet til transformationen, må sangen som motiv ses som redskab til at udtrykke det indgreb udefra, teksterne fastholder ved, at den situation, de taler ind i, gennemgår en markant ændring. I sin egenskab af svar på ændringen omtales glæden $\mathrm{i}$ de to første salmer som korrelat til sangen. "glade vi til Kirke gaae" og "Saligheds Fryd" viser det. I den tredje klinger sangen "livsaligst", også et tegn på glæde.

\section{To tekstvarianter - to tilgange}

Afsnittet undersøger baggrunden i Grundtvigs arbejdsliv og sprogverden for en ændring i "Blomstre som en Rosen-Gaard", str. 12, ved genudgivelsen i 1868 af Sang-Vark til den Danske Kirke I (GSV I, 303; GSV VI/1, sp. 1, 52). Det vises, at ændringen med rimelighed kan knyttes til en forskydning fra individuel til kollektiv synsvinkel hos digteren i sammenhæng med et skifte i vilkårene for hans arbejde med fornyelse af menighedssangen. Det belyses også, hvorfor valget af glosen "Engle-Sang" er egnet til at udtrykke ændringens baggrund. 


\section{Tekstomtale}

I 1868 ændrer Grundtvig linjerne

Medens vi, som tale end,

Troed, tvivled, traf igien

Herrens Aand i Støvet!

(GSV I, str. 12, 303)

til

Medens vi, som tale end,

Sukked, mødte os igien

Engle-Sang fra Støvet!

$(G S V \mathrm{VI} / 1, \mathrm{sp} .1,52)$

Ændringen foretages på et sted, hvor stemningen i salmens tredje afsnit skifter fra mørke til lys, og må derfor anses for betydningsfuld. Overordnet kan det konstateres, at motivkomplekset i str. 1 vender tilbage $\mathrm{i}$ intensiveret form i str. 15, men vejen dertil er lang. Forløbet er treleddet med bibelsk forjættelse og opfyldelse i salmens to første afsnit. Det tredje begynder med en afvisning af det fremførte, førend der indtræder en vending i str. 12 (str. 1-5 og 6-9 over for str. 10-15).

Digtets tredje afsnit er kendetegnet ved, at vendingen sker på baggrund af en periode, der ses som en nedgangstid af radikal art. Først omtales denne nedgangstid som tavshed og mangel på lydhørhed (str. 10), men i str. 11, digtets absolutte lavpunkt, skærpes dette til direkte fornægtelse af, at Jesu ord kan have gyldighed for mennesker i digtets nutid. Vi møder en konsekvent modsigelse af mulighederne i str. 1-5 og 6-9. Henvisningen til Joh 16,16a: "En kort tid, så ser I mig ikke længere", som det eneste troværdige Jesus-ord, lader imidlertid ane, at lavpunktet ikke er slutpunktet. Joh 16,16 fortsætter jo: "og atter en kort tid, så skal I se mig". Vendingen, der omtales i str. 12, antyder da også et lyssyn, som kan minde om det i str. 1, 6 og 15, selv om der endnu kun er tale om et morgengry, ikke det fulde dagslys med dets "Straale-Dands", som i str. 15. De sidste tre strofer bringer i omvendt rækkefølge og $\mathrm{i}$ aktualiserende form de to indledningsafsnits vigtigste motiver: lytte- og taleevne, dåb og nyskabelse med tilhørende genoplivelse af salmesangen. ${ }^{5}$ Intensiveringen af motiverne fører til, at den nye tids særpræg ikke kun beskrives ved, at naturens "FugleSange" bliver til historiens "Glade Nytaars-Sange" (min kursivering. "Glæde" er den dominerende glose i forlægget Es 35,10.). Den udtrykkes også med en af Grundtvigs yndlingsgloser: "Gylden-Aar". 6 


\section{Vendingen i digtet}

I str. 12 angives i 1837 årsagen til, at digteren ser anderledes på situationen, således: "vi, som tale end, / (...) traf igien / Herrens Aand i Støvet". Denne korte formulering minder påfaldende om den fyldigere udformning af mødet mellem ånd og støv i digtet "Jeg kiender et Land", 1824:

\section{O himmelske Navn!}

Som aabner fore vores din hellige Favn,

Saa Aanden, usmittet, kan røre ved Støv,

Og levendegiøre det visnede Løv,

O lad mig nedknæle saa dybt i mit Leer,

At Gud mig kun seer!

(GSV III, str. 8, 147. Min kursivering)

Thodberg 1989, 269-271, fremdrager billedsproget i denne og den foregående strofe, der taler om, at "Kiærligheds Aand" med sin "straalende Haand" "rører vort Øie med Fingre som Guld". Han antager, at der peges tilbage på en oplevelse, Grundtvig beskriver i digtet "Til Sibbern". Den indtraf under et hvil i en skov ved vejen nær afslutningen af hans rejse til Udby fra København efter hans ordination, da han ved pinsetid 1811 skulle tiltræde som kapellan hos sin far. Ved den lejlighed forenede synet af lysindfald gennem en nyudsprungen bøgeskovs sarte, grønne blade hen over det tørre, brune løv, der lå på skovbunden fra året før, sig med læsningen af 1 Kor 15,57, om "sejren ved vor Herre Jesus Kristus". Det giver ham mod til at gå i gang med præstegerningen (US II, 124-126. Thodberg 1989, 242-244).

Biografisk indtræder vendingen på baggrund af, at digteren forud har været igennem en meget bevæget tid. Efter en selvsikker periode i efteråret 1810, hvor han så sig selv som en ny Martin Luther, havde han sidst på året været rystet af en anfægtelse, der bragte ham på sindssygens rand og toppede, da han den berømte nat på Vindbyholt kro mente sig omklamret af Djævelen i en slanges skikkelse. ${ }^{7}$ Rækkefølgen selvsikkerhed, anfægtelse, ny fortrøstning svarer godt til 1837formuleringen i str. 12, at "vi (...) / Troed, tvivled, traf igien / Herrens Aand i Støvet". Det er svært ikke at se Grundtvigs personlige, religiøst-kristelige opgør som mønster for den formulering, der udtrykker vendingen fra mørke til lys i salmens tredje afsnit i $1837 .{ }^{8}$

Vendingens følger viste sig først på det personlige plan, som profetiens opfyldelse "i (...) Løn" (GSV I, str. 6, 301). Det ses af udskiftningen af den overmodige tanke om at være en ny Luther med accepten af først gerningen som faderens kapellan i Udby og derefter det slidsomme og lidet anerkendte arbejde som tænker, taler og skjald. Den 24. november 1811 skriver Grundtvig i fortalen til Saga. Nytaarsgave for 1812, den samling digte fra 1810-11, der rummer "Til 
Sibbern" med omtalen af skovoplevelsen i forsommeren 1811: "Harpen, som jeg hængde over Herrens Alter, rakde han mig selv igen, da han havde indviet den til sin, og med frit Mod griber jeg i de nystemmede Strænge" (US II, 94).

$\mathrm{Da}$ "Blomstre som en Rosen-Gaard" omsider kom til verden i 1837, havde Grundtvig set den nyorientering om salmesangen, han omtalte i forordet til Saga (...), berøre andre. Sang-Vark til den Danske Kirke, 1837, er selv det tydeligste tegn herpå gennem de mennesker, der støttede udgivelsen. Deltagerskaren ved hans aftengudstjenester i Frederikskirken med en dertil knyttet kreds af meningsfæller og venner er et andet. Lysstriben i forsommerskoven, morgenskæret i dagningen, var tiltaget, selv om det endnu ikke var blevet højsommer med fuldt dagslys i folk og kirke. Det var det, med hensyn til salmesangen, forlængst blevet i 1868, da Sang-Vark (...) kom i 2. udgave.

\section{Grundtvig og salmesagen}

\section{Et tilsagn og et tilløb}

I forbindelse med Grundtvigs livslange arbejde med salmen som menighedssang falder to tidlige tekster i øjnene. Den første er en passage fra fortalen til digtet "De Vise fra Østen", 1810 (GSV II, 197200), da det blev udgivet i Sandsigeren i april 1811. Her fremføres det synspunkt, "at en Samling af kristelige, mest historiske Sange vilde være Mange kjærkommen (...)”, og han tilføjer: "og en saadan agter jeg at udgive, om Gud under Liv og Helsen. Endel skulle være selvgjorte (...)" (US II, 79).

Den anden tekst er salmen "Som tørstige Hjort monne skrige", 1812 (GSV III, 66-68), der er en strofisk, rimet parafrase over Sl 4243. Den blev trykt i Saga. Nytaarsgave for 1812 med titlen "Klagesang" og står foran et digt fra 11. april 1811 til Constance Leth. Er disse to digte anført kronologisk efter tilblivelse, rykker "Som tørstige Hjort (...)" nær julen 1810, der tidsmæssigt er krisens midtpunkt. Sidste strofe lyder:

Hans Lys og hans Sandhed skal føre

Mig op til hans Tempel i Fred,

Der Ordet mit Hjerte skal røre

Og glemme jeg skal, hvad jeg leed;

Ja, selv skal jeg røre min Tunge

Til Psalmer for Herren at sjunge

Til Lov og til Pris for min Gud.

(GSV III, str. 7, 68)

Her bringer et ord, der kommer udefra, trøst og fremkalder et svar, en struktur, som i gudstjenestesammenhæng svarer til mønsteret 
forkyndelse/salmesang. Hørt som personligt udsagn har strofens tre sidste linjer klang af det ønske om selv at medvirke til en fornyelse af salmesangen, digteren fremfører i fortalen til "De Vise fra Østen".

I Festsalmer, 5. oplag, 1853, kom salmen "Deilig er den Himmel blaa" (GSV IV, 400-401), en forkortet version af digtet fra 1810, nu en af vores mest brugte julesalmer. "Som tørstige Hjort (...)" måtte vente til 1873, før den indgik i menighedens fællessang ved optagelsen i $R T$. Grundtvig selv havde i mellemtiden foretaget nye gendigtninge af S1 42-43. To kom i 1837 (GSV I, 295-298. III, 270-271), og en sidst i 1840'erne (GSV IV, 269-270), så inspirationen fra stoffet fra krisens tid har stedse rørt på sig.

Begge de tidlige digte lever op til det dobbeltkrav til en evangelisk salme, nu afdøde biskop Johs. W. Jacobsen, Viborg, formulerede i forbindelse med 1970'ernes og 1980'ernes drøftelser om salmesangens fornyelse: "Den skal være evangelisk ægte og digterisk forløst". I opfyldelsen af dette dobbeltkrav gemmer sig hovedårsagen til, at disse Grundtvigs tidlige digte med kristne motiver kan ses som frøkorn, der i tidens løb skulle udfolde sig som den blomstervang med vækster til sammensætning af de højst varierede buketter, hans digtning stadig kan berige dansk salmesang med.

\section{Egne forslag}

Som nævnt ovenfor omtaler Grundtvig i 1811 håbet om en genopretning af salmesangen i Danmark og sit eget ønske om at medvirke til det. Foreløbig blev det til lejlighedsbestemte arbejder i 1817 ved reformationsjubilæet og mere personligt motiverede som "Velkommen igien, Guds Engle smaa", 1824 (GSV I, 405-406) og "Tør end nogen ihukomme", 1825 (GSV I, 60-63).

I forbindelse med 1000-året i 1826 for Ansgars komme til Danmark havde præsterne undtagelsesvis fået lov til ved gudstjenesterne på pinsedag selv at vælge nogle af salmerne. Grundtvig lod trykke et salmeblad, der blandt andet rummede hans for os at se mesterlige gendigtning af, som han skrev: "den ældgamle Danske Dag-Vise, (Morgen-Salme) (...)" ( $A M \mathrm{I}, 163)$. Initiativet blev afvist af biskop Münter, og gendigtningen fandt ikke nåde for datidens smagsdommere. ${ }^{9}$

I 1837 kommer Grundtvigs største digtsamling, Sang-Vark til den Danske Kirke. Den åbnede manges øjne for bredden og dybden i den gamle salmetradition og gav Grundtvig en uomgængelig position i arbejdet med den fornyelse af salmesangen, der tog fart først $\mathrm{i}$ 1840 'erne. Selv lod han til brug ved gudstjenesterne i Vartov i julen 1845 trykke et salmeblad med egne salmer. Med udgangspunkt heri og senere salmeblade til andre højtider udgiver han derefter fra 1850-70 i 
stedse øgede oplag Festsalmer, der blev grundstammen i de grundtvigske fri- og valgmenigheders salmetradition. ${ }^{10}$

\section{Vejen til anerkendelse}

I løbet af 1830 'erne var vejen for en bredere indsats fra Grundtvigs side blevet beredt af andre med samme sans for menighedens behov, men de fleste med mindre evne til selvstændigt at opfylde det adækvat. Selv B. S. Ingemann, der kan stå som den fineste repræsentant for det poetiske nybrud $\mathrm{i}$ genren, når først sit højdepunkt med Morgensalmer for Børn, 1837. Betydningsfuldt er det, at der kommer en række nye udgivelser af de gamle salmer, men det er heller ikke uvæsentligt, at der trykkes samlinger af nydigtede salmer, selv om langt de fleste senere viste sig ikke at være langtidsholdbare. ${ }^{11}$

I begyndelsen af 1840'erne blev de første forsøg på at forny den officielle salmesang sat i værk. Både oprøreren Grundtvig og opsynsmanden Mynster deltog i arbejdet, der sluttede med udgivelsen af Kirke-Psalmer udgivne til Prøve af Kjøbenhavns geistlige Konvents Psalme-Comite, 1845, også kaldet Prøveheftet. Her er de to første strofer af "Giv mig, Gud, en Psalme-Tunge" brugt som en art forord (GSV I, str. 1-2, 152). Tidsmæssigt sammenfaldende hermed møder vi en ny optimisme i forbindelse med Grundtvigs fremstilling af julebudskabets udsagn om glæden for hele folket (Luk 2,10). I 1825 ses der frem mod glæden med bønnen: "O, maatte vi kun den Glæde see, / Før vore Øine lukkes!" (GSV I, str. 8, 406). I 1846 er den blevet nærværende med de strålende øjne i linjerne: "Hvor Aand har Mæle og Sang har Væld, / Hvor Øine tindre hvert Julekvæld" (GSV IV, str. 16, 212). Det tidsmæssige sammenfald med Prøveheftets markering af, at der er kommet bevægelse i salmesagen kan antyde en inspirationsfremmende impuls fra hæftets tilblivelsesforløb. Alt var dog ikke lykkedes endnu. Der var stadig kun tale om en prøve.

I 1850 og 1852 fremlægges forarbejder til en forordnet salmebog, der kommer i 1855 med titlen Psalmebog til Kirke- og Huus-Andagt, også kaldet Roskilde Konvents salmebog. Her optages en række af de salmer, menighederne havde savnet, og som Grundtvig og hans ligesindede var de første til at kæmpe for. Dertil kom et antal nye salmer. Timm og Boye fik således officiel status sammen med B. S. Ingemann. Grundtvig selv blev rimeligt repræsenteret både med oversættelser, bearbejdelser og egne salmer, flere med ændringer, der ikke alle påkaldte sig hans udelte begejstring. ${ }^{12}$ Alligevel foreligger der en reel accept af han forsvar for de "gamle" salmer. 


\section{“Rosen-Gaardens" plads i forløbet}

Når den fornyede italesættelse af omsvinget i 1810-11 mange år efter denne accept netop sker i "Blomstre som en Rosen-Gaard", skyldes det sandsynligvis den bagvedliggende tekst, Es 35,1-7.10. Den har uden vanskeligheder kunnet føre Grundtvigs tanker tilbage til det skelsættende forløb, som faldt tidsmæssigt sammen med hans første forsøg med salmedigtningen og hans indtræden i præstegerningen, der ved samme lejlighed for ham skiftede karakter fra familiær pligt til eksistentielt anliggende. Der er to eksempler på tekstens betydning i denne sammenhæng.

Det ene er hans brug af Es 35,1.6b-7, som motto for RoskildeRiim. Digtet blev i kortere skikkelse end den trykte udgave reciteret af forfatteren ved landemodet i Roskilde den 4. Oktober 1812, og dets strofiske fortale til Frederik VI er dateret juleaften 1813 (RoskildeRiim, 1814, titelblad og upagineret side før s. 1. US II, 423-427). Tidsmæssigt er vi heller ikke langt fra "Til Sibbern" fra juni 1811 med det opmuntrende skriftsted 1 Kor 15,55-58, der i skovoplevelsen forenede sig med synet af det grønne forsommerløv på de solbeskinnede bøgegrene (US II, 125-126. Thodberg 1989, 242 -244), og "Udby Have" med omtalen af "Herrens Lyn", der ifølge digtets udsagn gengav ham sansen for de gamle salmer (US II, 137).

Det andet er digtet "Kammersvenden fra Morland" (GSV III, 66-77 og II, 274-279). Grundtvig oplyser ved udgivelsen i Kvoedlinger, 1815, at det er fra 1812, og det står lige efter "Skjaldelivet", som han daterer til "tidlig" i 1812 (US III, 87 og 80). Uanset mulige unøjagtigheder i disse dateringer er vi tilbage i hans tid som kapellan i Udby. Digtets første 26 strofer er en bredt udfoldet genfortælling af ApG 8,26-40, om den ætiopiske hofmands dåb. Resten, str. 27-35, er digterens meditation over hændelsen. Her er Es 35,1-7, om den "øde Vang", der blomstrer, og om "Den tavse Ørk med Jubellyd" sammen med ordene fra Matt 13,17, om opfyldelsens stund med Jesu komme lagt hofmanden i munden ved hans hjemkomst (str. 29-32). Digtet slutter med digterens og ætioperens fælles "Halleluja! / Med Himmelske Hærskarer" (str. 35, 6-7).

Meditationen i "Kammersvenden (...)" viser in nuce forløbet $i$ "Blomstre som en Rosen-Gaard", 1837, str. 1-10, men disse 25 år senere står Esajas-teksten alene. Det lange, fortællende afsnit fra "Kammersvenden (...)" er udeladt, og afslutningen omtaler ikke længere den evige salighed, men en omskiftelig periode, hvor en udsigt til bedre dage ses at følge efter en trang tid. Ved denne koncentration om Es og ved treklangen forudsigelse, opfyldelse i historien og håb for den nære fremtid erstattes en (lidt for rigelig) episk bredde af en betydelig poetisk kraft. 
I 1843 er både den fornyede natur og den genfundne sang fra Es og "Kammersvenden (...)" til stede i pinsesalmens opfordrende indledningslinjer:

Opblomstrer nu, Guds Kirkevange!

Gienlyder trindt af Lærkesange!

$\mathrm{Nu}$ kom vor Pindselilje-Tid,

$\mathrm{Nu}$ har vi Sommer blank og blid (...)

(GSV III, str. 1, 514)

Dobbeltmotivet blomster og sang er intakt, mens den danske digters og den ætiopiske hofmands deltagelse i de himmelske hærskarers Halleluja i evigheden er blevet til, at "Det evige Halleluja" nu ses som en opløftende hændelse, der når som helst kan indtræffe hos alle folkeslag:

I Jesu Navn da Tungen gløder

Hos Hedninger saa vel som Jøder;

I Jesu Navn og Offerskaal

Hensmelte alle Modersmaal;

I Jesu Navn udbryder da

Det evige Halleluja!

(GSV III, str. 6, 515)

I 1853 ændres pinsesalmen fra 1843 til offentliggørelse (GSV VI/2, 267). Samtidig udtager Grundtvig syv strofer af "Blomstre som en Rosen-Gaard", 1837, og med en række små, men kvalitetsforbedrende ændringer i ordlyden danner han den kendte gudstjenestesalme ( $G S V$ IV 343-44). Man kan ud fra praktiske overvejelser om en salmes længde og om nødvendigheden af at være særdeles omhyggelig med dens sprogbrug argumentere for, at bearbejdelsen er vellykket. Ganske vist har digtet herved mistet personal- og kirkehistorisk dybde og dermed også tabt i eksistentiel intensitet, men der er kommet en uomgængelig festsalme til brug i adventstiden ud af det. ${ }^{13}$

De to salmer står som nr. 736 og 740 i Festsalmer, 5. oplag, og begge salmer medbringer glæden som korrelat til sangen. Selv om glosen 'glæde' ikke bruges i pinsesalmen, gennemstrømmer fænomenet 'glæde' hele teksten. I sidste strofe af "Blomstre som en Rosen-Gaard" er "Fugle-Sange" gennem hele tekstens historie transformeret til de "glade Nyaars-Sange" (min kursiv), der bringer bud om et "GyldenAar".

I 1853 viger håbsmotiverne: blomster og fugle, i pinsesalmens indledningslinjer pladsen for solen og lyset som bekræftelse på opfyldelsen i Kristus nu i dag og her hos os: 
I al sin Glands nu straaler Solen,

Livs-Lyset over Naadestolen, (...)

(GSV VI/2, sp. 1, 267)

men motiverne slippes ikke. Ved et så enkelt middel som at udskifte et udråbstegn med et komma ændres opfordringen i str. 2 til "Fredskovens Nattergale" om at synge højt til en konstatering, så fuglesangens betydning forstærkes. Derudover består bearbejdelsen af en tilføjet strofe, hvis to første linjer lyder:

Vor Gud og Fader uden Lige!

Da blomstrer Rosen i dit Rige (...)

(GSV VI/2, sp. 2, 267)

Ved brugen af rosen er blomstermotivet blevet mere konkret, og placeringen i slutstrofen har givet det øget vægt. Her kan arbejdet med "Rosen-Gaarden" ses som element i en trefoldig inspiration, hvis andre kilder er rosen i Marie Tofts slægtsvåben og rosen som alment kærlighedssymbol. Parallellen til linjerne:

Blomstre som en Rosen-Gaard

Skal de øde Vange!

(GSV IV, str. 1, 343)

er i hvert fald påfaldende.

Da den korte udgave af "Blomstre som en Rosen-Gaard" i 1864 får sin endelige form gennem den teologisk mere præcise ordlyd "Sammen" i stedet for "Begge" i str. 13, 3, kan man konstatere, at Grundtvig igen har haft profetteksten for øje eller in mente, som det har været tilfældet adskillige gange gennem mere end 55 år, når han har arbejdet med digte, salmer og udgivelser. ${ }^{14}$ Sammen med afkortelsen og tekstændringerne i salmen i de forskellige oplag af Festsalmer viser det skifte fra håb til fortrøstning, der ses i ordvalget til juleforkyndelsen mellem 1825 og 1846 og i pinseforkyndelsen mellem 1843 og 1853, at Grundtvig både er afhængig af og opmærksom over for den betydning, som såvel karakteren af den tid, teksterne bliver til i, som den situation, de taler ind $\mathrm{i}$, har for forståelsen af dem.

På den baggrund er det ikke overraskende, at han i 1868 ved mødet med Esajas' blomster og fuglesange ved genudgivelsen af Sang-Vark (...) fra 1836-37 sætter nye ord på "Den sælsomme Forvandling" (Michelsen 1956) og gør det ud fra dens langtidsvirkning som medvirkende kraft ved fornyelsen af den danske salmesang. Også over for egne tekster er digteren indstillet på "de Forandringer, Tiden med Ret kan fordre" (US II, 79). 


\section{Sammenfatning}

Da Grundtvig i Kvaedlinger, 1815, genudgiver den lille digtsamling Nytaarsnat, 1810, skriver han i et "Tillæg", at samlingen bærer sit navn med rette. Han henviser til folketroens tale om, at man denne nat kan ane, hvad det kommende år vil bringe (US II, 69). Da Nytaarsnat kom første gang, kunne hverken Grundtvig eller nogen anden i samtiden være klar over, at hændelsesforløbet i vinteren 1810-11 skulle medvirke til at iværksætte et skift fra ødemark til blomstervang i den danske kirkes og menigheds liv. Da dette hændelsesforløb i 1836-37 inddrages i gendigtningen af den profettekst, som i hvert fald tidsmæssigt var nært knyttet til forløbets afgørende fase, der rent praktisk havde præstegerningen i Udby som konsekvens og Roskilde-Riim, 1814 , som udadvendt poetisk følge, forbindes det alene med en erindring og erkendelse hos digteren selv.

Den erkendelse var ganske vist en del af forudsætningerne for et svar på hans ønske om en regeneration af kristendommen i Danmark og dermed en fornyelse af salmesangen. Det har han givetvis været sig bevidst i 1837, men den forståelse deltes endnu kun af det fătal af hans samtidige, der i ham så den digter, der kunne give denne fornyelse kraft. Derfor formes str. 12,5-7, på dette tidspunkt nok som udtryk for en opfyldelse af profetien om at gøre "Paradis af Ørke" (str. 6, 7), men den er kun sket for ham selv personligt og er endnu kun anerkendt af få. Der er tale om en opfyldelse "i Løn" (str. 6, 6). Det fører ud fra mindelserne om den helt private skovoplevelse til ordlyden:

Medens vi, som tale end,

Troed, tvivled, traf igien

Herrens Aand i Støvet!

(GSV I, str. 13, 1. 5-7, 303)

Da digtet gennemses i 1868, synes opmærksomheden i stedet eller desuden at have samlet sig om hændelsesforløbets følger udadtil. Det viser sig i, at sangmotivet fra "Fugle-Sange" i str. 1 og "NytaarsSange" i str. 15 bliver betydningsbærende i str. 12 som "Engle-Sang". Desuden er det komma, der meningsmæssigt står efter strofen i 1837, på vej til at blive til et semikolon, en pause af samme omfang som pauserne efter str. 5, hvor sangmotivet forekommer som "FrydeSang", og str. 9, hvor den stammende begynder at tale. Sammen giver det sangmotivet en øget vægt, der markerer et skift i den videre kontekst ved, at fornyelsessituationen nu helt tydeligt beskrives som et anliggende, hele menigheden er optaget af. Digterens "vi" er blevet til et kollektivt "vi".

Endvidere neddæmpes det spændingsmoment, der i 1837 optræder som et personligt anliggende i modstillingen "Troed, tvivled" i str. 12, 
6. I 1868 fremtræder erindringen herom i form af mindet om modløse stunder. Skiftet fra personligt-eksistentielt til psykologisk-socialt synspunkt tyder på brug af mere erfaringsmateriale end den individuelt-private erkendelse i anfægtelsen og skovoplevelsen. Her er det fælles ønske med kredse i menighederne om salmesangens fornyelse den mest nærliggende mulighed. Også de tidlige tekster er derved kommet $\mathrm{i}$ et nyt lys. De kan nu ses som reelle forvarsler, ikke kun ønsker, om den forvandling, digteren i hine tider håbede på. Hele forløbet er blevet et tegn på, at profetiens opfyldelse lader sig se i menighedens forsamling. ${ }^{15}$ På den måde er den trådt ud i et offentlig rum. Den er endelig sket "i Lys". Derfor må det nu, med min fremhævelse, hedde:

Medens vi, som tale end,

Sukked, mødte os igien

Engle-Sang fra Støvet!

$(G S V \mathrm{VI} / 1$, sp. 1, 52)

Poetisk og eksistentielt er den ændrede ordlyd svagere. Bogstavrimets bortfald mindsker det markante præg, og indholdsmæssigt står "Sukked" tamt over for "Troed, tvivled". Brugen af "Engle-Sang" er imidlertid afgørende, fordi den er bestemt af digterens syn på salmesangens funktion som medbærer af og aktivt, eksistentielt svar på evangeliets forkyndelse og på dåbens befrierhandling og nadverens livsopholdende kærlighedsgave.

\section{To tekstvarianter - en tankegang}

Ud fra den antagelse, at de to nedenfor anførte tekstvarianter er tænkt som udsagn om, at og hvordan sangmotivet markerer en ny situation, opsøges deres fælles betydningsmæssige og sproglige baggrund i nogle af Grundtvigs jule- og nadversalmer. Der argumenteres for, at inkarnationen forstået som historisk, varig hændelse sammen med brugen af teksten ved almindelige gudstjenester fastholder udsagnets meningskonstans trods den ændrede ordlyd, og at netop salmens brug som almindelig gudstjenestesalme kan have været medvirkende årsag til ændringen. Også i denne tekst er glæden et fast korrelat til sangen.

\section{Tekstomtale}

I Festsalmer, 8. oplag, 1864, ændrer Grundtvig i salmen "Midt iblandt os er Guds Rige", 1853, de to linjer, der i Festsalmer, 5. oplag, 1853, havde haft ordlyden 
Og naar Herrens Fødsels-Glæde

Raabes ud med Engle-Røst (...)

(GSV IV, str. 6, 345)

til

Og naar Herrens Himmel-Glæde

Raabes ud med Aande-Røst (...)

(GSV VI/2, sp. 1, 335)

Salmen er opbygget med en introduktion og et tredelt korpus, hvor str. 1 udgør introduktionen, der præsenterer Guds Rige som en nutidig, nærværende virkelighed. Str. 2-4 beskriver vilkåret for rigets nærvær som usynligt og henviser til Åndens gerning i forkyndelse og tro, idet str. 4 antyder dåb og nadver som stederne, hvor ordet lyder på en sådan måde, at det kalder på troen. Det sker gennem kombinationen "Ord og Aand" (1. 2) og glosen "smage" (1. 3). Med de mere indholdsprægede gloser retfærdighed, fred og glæde fra Rom 14,17, bestemmer str. 5-6 den nærmere karakter af riget, så opmærksomheden rettes mod en omtale af dets følgevirkninger frem for at beskrive dets vilkår. På dette sted i salmens struktur og tankegang indføres sangmotivet som bærer af glæden. Str. 7-9 bringer som afrunding bibelske billeder af det usynlige riges følgevirkninger for menneskets eksistens og ser frem til dets synliggørelse ved Kristi Genkomst. ${ }^{16}$

\section{"Fødsels-Glæde" og "Himmel-Glæde"}

\section{Juleglaede og Frelserens komme}

Med den tydelige henvisning til Luk 2,10 er det naturligt at søge Grundtvigs forståelse af udtrykket "Herrens Fødsels-Glæde" præciseret ved læsning i hans julesalmer. Det viser sig, at den glæde, som fremkaldes ved Frelserens fødsel og "Raabes ud med Engle-Røst", og som altså kommer udefra, må bæres videre. Det fremgår blandt andet af, at gæstemotivet med den fremmede, der kommer på besøg og bringer liv i huset, men ikke har fast ophold, indgår på naturlig måde som betydningsbærende element i sammenhængen. Det er der klare udtryk for $\mathrm{i}$ to af Grundtvigs mest kendte julesalmer. Den første er fra 1817:

Det kimer nu til Jule-Fest,

Det kimer for den høie Giæst,

Som steeg til lave Hytter ned

Med Nyaars-Gaver: Fryd og Fred!

O, kommer med til Davids Bye, Hvor Engle sjunge under Skye! 
$\mathrm{O}$, ganger med paa Marken ud,

Hvor Hyrder høre Nyt fra Gud!

Kom, Jesus! vær vor Hytte-Giæst!

Hold Selv i os Din Jule-Fest!

Da skal med Davids-Harpens Klang

Dig takke høit vor Nyaars-Sang!

(GSV III, str. 1-2, 126; 24, 129)

Den næste er "Velkommen igien, Guds Engle smaa", 1824 (GSV I, 405-406). Både denne salmes vemodigt prægede bøn om ikke at gå glip af besøget, om, at den ægte julesalme igen må blive hørt og sunget, og om, at "Jule-Sorgen" derved må slukkes, og den festlige opfordring i 1817 er stærke udtryk for betydningen af "Herrens FødselsGlæde" som den udefra kommende glæde, der må bæres videre. Begge steder kombineres denne "Fødsels-Glæde" med gæstemotivet og den tilhørende hytte. Derfor ligger det lige for at inddrage Grundtvigs elskede Johannes-evangelium, der om den hændelse, salmerne udspringer af, siger: "Og Ordet blev kød og tog bolig iblandt os, og vi så hans herlighed, en herlighed, som den Enbårne har den fra Faderen, fuld af nåde og sandhed" (Joh 1,14).

Her har "tog bolig" intet at gøre med erhvervelse af fast ejendom. "Bolig" henviser til den mobile helligdom, Tabernaklet, som Gud i fortællingerne om de tolv stammers vandring fra Sinai til Det forjættede Land bruger som opholdssted. Den græske glose skcence, der bruges om denne ørkenhelligdom i $L X X$, som det eksempelvis kan ses i 2 Mos 26 og 40,34-39, betyder primært et telt eller en hytte og ligger tydeligt bag udsagnsordet skanóå, som $A O$ gengiver: tog bolig. Helt præcist kunne det gengives: slå sit telt op, bo i telt. Det næsten enslydende udsagnsord skanéå betyder at opholde sig, bo, sove, spise i et telt med hovedvægten på det sidste. Der er tale om at leve under mere eller mindre interimistiske forhold, som for eksempel soldater i krig og nomader gør det. ${ }^{17}$ Efter at alle enkeltheder om tilvirkning og inventar er opregnet, hedder det om Tabernaklet: "Det skal være en evig ordning, slægt efter slægt, hos israelitterne" (2 Mos 27,21). Teltet taler således om, at når Ordet er hos os helt ud $\mathrm{i}$ vore vilkårs yderste kroge og fattigste former, er det ikke kun flygtigt og forbeholdent, men varigt og helhjertet.

Også Luk 2,7: "og hun fødte sin søn, den førstefødte, og svøbte ham og lagde ham i en krybbe, for der var ikke plads til dem i herberget”, må inddrages. Uanset om det græske katályma, som der ikke var plads i, var et herberge eller kammer, er det mest sandsynligt, at krybben var placeret eller udhugget i en som stald benyttet klippehule, der var en almindelig forekomst $\mathrm{i}$ Bethlehem, og som stod ubenyttet, når 
dyrene, som i Lukas' fortælling, var på marken. Hulen kunne derfor benyttes som gæstebolig, men der er tydeligvis tale om et både midlertidigt og såre beskedent logi. ${ }^{18}$

\section{Inkarnationens ydre vilkår}

Tanken om den inkarneredes vilkår som ikke blot fremmed og gæst, men også som uønsket og ildeset mellem mennesker optræder også allerede i forbindelse med fortællingerne om Frelserens fødsel: "Han kom til sit eget, og hans egne tog ikke imod ham" (Joh 1,11), og "Herodes ville søge efter barnet for at slå det ihjel" (Matt 2,3). Den tradition har Grundtvig bevidst forholdt sig til i sin salmedigtning. Det kan ses af hans arbejde med Brorsons julesalme "Mit hierte altid vanker", 1732 (BSS I, 32-35), som han har gendigtet både i $1837 \mathrm{og}$ 1845. Særlig Brorsons str. 3, som Grundtvig bruger som begyndelsesstrofe, påkalder sig interesse. Brorson skriver:

Men ach! hvad skal jeg sige

Naar jeg vil tænke paa,

At Gud af himmerige

I stalden ligge maa,

At himlens lys og ære,

Guds væsentlige ord

Skal saa foragtet være

Paa denne slemme jord.

(BSS I, str. 3, 33)

Det får hos Grundtvig to former:

1837:

Hvad maa mit Hjerte sige:

Naar ret jeg tænker paa

At Gud af Himmerige

I Krybben ligge maa,

At Himlens Fryd og Ære,

Det store Skaber-Ord,

Skal saa foragtet være

Paa denne usle Jord!

(GSV I, str. 1, 383)
1845:

Forunderligt at sige

Og sært at tænke paa,

At Kongen af Guds Rige

I Stalden fødes maa,

At Himlens Fryd og Ære,

Det levende Guds Ord,

Skal huusvild blandt os være

Som Armods Søn paa Jord!

$(G S V \mathrm{VI} / 1, \text { sp. } 2,68)^{19}$

Et andet vidnesbyrd om, hvor rodfæstet dette syn på inkarnationens ydre vilkår er hos Grundtvig, finder vi i salmen "Den Husvilde", 1856 (GSV V, 19-20). Det dukker op i linjerne:

Saa gaaer Vorherrre med Naadens Ord

Husvild og fattig omkring paa Jord!

$(G S V$ V, str. 1, 19) 
og dets yderste konsekvens møder vi i udsagnet:

Dengang Vorherre gik synligt omkring,

(...)

Utak han fik mod al Ret og Skjel,

Til han paa Korset blev pint ihjel.

$(G S V$ V, str. 3, 20)

Ikke desto mindre optræder "Den Husvilde" som en gæst, der bringer trøst og glæde til huse hos "de Milde", der svarer med at formidle bekendelsen ved at synge: "Jesus den Christus!" (GSV V, str. 4-6, 20). Salmens sidste linjer:

Han har dog Livet og Lykken,

Deler dem ærligt med hver som troer:

Aanden og Livet er i hans Ord!

$(G S V$ V, str. 7, 20)

markerer, at den glæde, der rummer "Livet og Lykken", ligesom "Rigets Frugt" i "Midt iblandt os (...)", str. 4, er knyttet til Ordet, Ånden og Troen:

Og naar vi med Tro modtage

Ord og Aand i Jesu Navn,

Rigets Frugt vi forud smage

I det søde Frelser-Navn! $!^{20}$

(GSV IV, str. 4, 345)

Inkarnationens ovenfor skitserede vilkår ifølge Grundtvig er med til at bestemme "Herrens Fødsels-Glæde" som en glæde, der kommer ind i en verden, der på egen hånd ikke rummer en stadig kilde til varig glæde. Samtidig er denne udefra kommende glæde båret af den nyfødte Frelser, der er udsat for de samme skrøbelige, omskiftelige og i sidste ende dødsmærkede vilkår, som denne verdens andre mennesker lever under. Uanset disse tilsyneladende ugunstige vilkår kan denne glæde dog opfanges og videregives af mennesker, fordi den har sin oprindelse $\mathrm{i}$ en ekstern instans, der modsiger sorgen og døden. Grundtvig kalder denne instans Gud, ser den afsløret for os i Jesus fra Nazareth og nutidigt nærværende i nadveren. Det sidste fremgår af det næste afsnit.

\section{Nadverglcede og Frelserens noervar}

Udtrykket "Himmel-Glæde" møder vi på særdeles karakteristisk måde i salmen "Apostlerne sad i Jerusalem", 1839-43 (GSV II, 263-264). Her bruger str. 1-2 den gamle almueforestilling om, at der tales om os, når det ringer os for ørerne, og str. 3 lyder derefter: 
Der taldes om dem, som Livets Ord

$\mathrm{Nu}$ skulde med Kraft forkynde, ${ }^{21}$

Om Himmel-Glæden ved Herrens Bord,

Som skulde paa Jord begynde.

Derefter følger en samtale mellem Faderen og Sønnen, hvor de beslutter at dele "Den Aand, som nu kun er min og din / (...) med Smaafolk (...)" (GSV II, str. 4-7, 92-93). Under vekslende betegnelser forekommer "Himmel-Glæden ved Herrens Bord", der må svare til "Herrens Himmel-Glæde", i flere af Grundtvigs nadversalmer. Mest karakteristisk er i den forbindelse salmen "Du er vor Skat, o Jesus sød!", 1837-1840 (GSV III, 362-365). Her findes to generelle udtryk for "Himmel-Glæden": "Fryd og Fred" (str. 1, 362) og "evig Fryd" (str. 13, 363), hvor det første helt svarer til julesalmens "Med NyaarsGaver Fryd og Fred" (GSV III, str. 1, 126). To andre udtryk knytter sig til måltidet: "Og ved mit Bord en evig Fest" (GSV III, str. 14, 363) og: "Saatit vi mødes ved dit Bord, / (...) lad os (...) / Inddrikke Barneglæden din" (str. 21, 364). Der er også et mere indirekte udtryk for "Himmel-Glæden": "Enhver, som troer; / Han dele skal min Kongestol / Og evig skinne som en Soel!" (str. 19, 364). Glæden gemmer sig vel også i det kærlighedsmotiv, der står meget stærkt som salmens sidste udsagn om den ultimative situation, at "Kiærligheden, Fader kaldt, / Din Gud, vor Gud, er Alt i Alt" (str. 23, 365).

I et langt indskud (GSV III, str. 8-19, 363-364) inddrages det modgangsmotiv, som ved "Fødsels-Glæden" var knyttet til inkarnationen, og som markeredes stærkt i "Den Husvilde". Udtryksformen er dog mere afdæmpet: "Med Torne strøet er Livets Vei" (str. 13, 363); "Lad mylre om Dig Mørkets Hær" (str. 14, 363); "Vær kun ei ræd, for Du er Muld" (str. 17, 363; for = på grund af, at). ${ }^{22}$

Familieskabet mellem "Himmel-Glæden ved Herrens Bord" og "Herrens Fødsels-Glæde" er også på færde i hvert fald i tre nadversalmer i den forstand, at engle på en eller anden måde fører ordet, som de gjorde det julenat:

1. "Mindes vi en fuldtro Ven", 1837 (GSV I, 634-635), er en gendigtning af en engelsk hymn med titlen "Remembrance of Christ" (Tekst med kildehenvisning i $A M$ III, 333). Hos Grnndtvig lyder str. 3:

Naar da om dit Nadver-Bord

Trindt og tæt vi tage Sæde,

Med den Tro, at i dit Ord

Du er sandelig tilstæde,

Minde dit er Glød i Bryst,

Har paa Læben Engle-Røst!

(GSV I, str. 3, 635) 
Hverken nadveren, englene eller den glæde, der i næste strofe er salmens sidste udsagn, er nævnt i den engelske tekst, men medvirker til at komme på sporet af, hvad "Minde dit" går ud på. Ved at være "Glød i Bryst" fremkalder det den "Engle-Røst", som må betegne en takkesang, der svarer til lovsangen for Frelserens komme julenat (Luk 2,14). Salmesangen ved nadverhandlingen som svar på Herrens nærvær i nadveren er denne sangs aktuelle udslag. "Minde dit" er den "ihukommelse", der er knyttet til uddelingen af brød og vin som redskaber for, at den nærværende Frelser nutidigt træder ind i også min tilværelse, når de ord, der følger uddelingen, høres til tro og på den måde røber Frelserens virkelige nærvær under nadverhandlingen. "Minde dit" handler altså ikke primært om, at "vi husker dig", men om, at måltidet med de ledsagende ord "(på)minder os om, at du er her", så vi med glæde takker for dit nærvær. ${ }^{23}$

2. Den allerede omtalte "Du er vor Skat (...)", 1837-40 (GSV III, 362-365), bringer efter henvendelsen til Jesus i str. 1 en meditativ beskrivelse af nadverelementerne i str. 2-3, hvorefter det i str. 3-4 lyder:

Dit Kjød er Mad, dit Blod er Drik,

Som ingen Overengel fik,

Det gjemde Du til dine Smaa,

Som troe, hvad Engle ei forstaae!

Det gavst Du hen til deres Trøst,

Som trygt sig hvile til dit Bryst,

Hvor Du er med din Englehær

Kun i dit Ord vort Hjærte nær!

For Øiet skjult, for Haanden tom

Du vandrer i din Helligdom,

Men kjendes dog paa Røsten din,

Naar Du velsigner Brød og Vin!

(GSV III, str. 4-6, 362)

Også julenat var Frelseren og englehæren samtidigt til stede, og netop den nat gjorde han menneskers liv og vilkår til den helligdom, der er lige så omvandrende som Åbenbaringsteltet i ørkenen og som Menneskesønnen, der ifølge "Den Husvilde" hverken har fuglerede, rævegrav eller sneglehus at søge ly i som "sit eget" (Matt 8,20). Også det lokale, hvor nadveren fandt sted, var lånt (Mark 14,12-16). At Grundtvig kan synge: "Kirke! du er vort Bethlehem" (GSV IV, str. 17, 212), om det hus, hvor den menighed, der blev skabt pinsedag, fejrer nadveren i nutiden, er vel et yderligere tegn på denne sammenhæng mellem Frelserens fødsel og Kristi nærvær i nadveren. ${ }^{24}$

3. Vekselvirkningen mellem englesangen julenat og menighedssangen ved altergangen forekommer også $i$ en strofe $i$ salmen 
"Vorherres Jesu Mindefest", der oprindeligt havde førstelinjen "Jesu søde Hukommelse" (GSV III, 471-473; V, 499-501). Strofen lyder:

Som Faderen, saa ærer dig Hvert Engle-Kor i Himmerig, Og som du elskes her paa Jord, Af Støv opelskes Engle-Kor! (GSV III, str. 10, 472)

En nærmere beskrivelse af denne lovsang for dobbeltkor findes i tre strofer, som Grundtvig, antagelig af hensyn til salmens længde, der oprindeligt var 16 strofer, udelod, da den kom i praktisk brug i 1847 (GSV VI/2, sp. 1, 319):

Syng høit og lavt i fulde Kor!

Syng lavt, du Himmel! høit du Jord

Saa smelter sammen høit i Sky,

Med Jesu Navn en Lovsang ny!

For Midleren, for Gud og Mand,

Den mægle skal paa Himlens Rand

Imellem alle Aanders Kor

Og alle Hjertesuk paa Jord!

Ja, Himmel! giør vort Suk til Nyn

Paa Lovsang din med Kraft og Fynd!

Engang skal vi forstærke da

Dit evige Halleluja!

(GSV III, str. 13-15, 472-473)

Lovsangen for dobbeltkor ved nadveren har en pendant i fødselsfortællingen i Luk 2 med engleskarens "Ære være Gud (...)” (v. 14) over for hyrderne, der vendte tilbage "og priste Gud for alt, hvad de havde hørt og set, sådan som det var blevet sagt til dem" (v. 20).

\section{Inkarnationen som falles baggrund}

Det hebraiske "Halleluja", på Grundtvigs tid oversat "Lovsynger HERREN", svarer meningsmæssigt aldeles til "Ære være Gud" fra englesangen julenat, hos Grundtvig gengivet netop med "Halleluja" i salmer som "Et Barn er født i Bethlehem", 1820, hvor det markeres med kolon i str. 3:

Guds Engle sang med Fryd derom:

Halleluja, Halleluja!

(GSV I, 353)

og "Et lidet Barn saa lysteligt", 1845, med linjerne:

Og naar vor Lovsang altid ny

Fra Hjertet svinger sig i Sky 
Med glade Juletoner,

Vort fattige Halleluja

Med salig Fryd istemmes da

Af Engles Millioner!

(GSV III, str. 2, 492)

Når vores suk kan blive til en glad nynnen med på den himmelske lovsang i forbindelse med, at der holdes nadver, på samme måde som "Vort fattige Halleluja" i forbindelse med fejringen af Frelserens fødsel "istemmes af Engles Millioner", og det tilmed stilles i udsigt, at vi derved kan forstærke "Dit evige Halleluja", må man sige, at der vanskeligt lader sig forestille et stærkere udtryk for vekselvirkningen mellem "Herrens Fødsels-Glæde "og "Herrens Himmel-Glæde" som "Himmel-Glæden ved Herrrens Bord".

Uden brug af sangmotivet, men overordentlig præcist møder vi parallelføringen af nadver og jul kombineret med en variant af hyttemotivet allerede i "Tør end nogen ihukomme", 1825, med strofen:

Verdens Vise, Jordens Bolde,

Vil vor Hytte vel forsmaae,

Men den Største vil dog holde

Nadver i den ringe Vraa;

Tidlig Han sig myg har krummet

Barneglad i Moder-Skiød,

Han som laae i Krybbe-Rummet,

Bryde vil i Hytten Brød!

(GSV I, str. 10, 62)

Koblingen mellem juleglæden og glæden ved nadverbordet findes naturligvis også i Grundtvigs prædikener. Fordelt over det meste af hans langvarige virke kan disse tre eksempler nævnes:

Juledag 1812 forbinder han barndommens måltid juleaften med "Julenadveren med Abraham, Isak og Jakob i Himmeriges Rige", og han husker "det Ønske (...), at vi vaagnede med en glædelig Fest i Hjerte og paa Tunge" (Bibelske Pradikener 1816, 87-88, her efter Thodberg 1989, 301). Skartorsdag 1853 hedder det "saaledes giør Guds Kicerligheds Ord det christelige Guds Bord til Guds Søns, Vorherres Jesu Christi Legems og Blods Samfund og Fællesskab, og mætter derved den troende Sjæl med Fred og Glæde: Guds Fred og Vorherres Glæde" (Vartovprcedikener v. H. Begtrup 1924, 317; her efter HGS III, 168-169). Pinsedag 1862 understreger Grundtvig i sin prædiken treklangen forkyndelse, dåb og nadver og følger op med tro, håb og kærlighed for at slutte med "Retfærdigheden, Freden og Glæden i den Helligaand, som er de kristnes Himmerig paa Jorden" (HGS III, 171). 
Uanset om glæden mest er knyttet til fejringen af Jesu fødsel, eller den forbinder sig i særlig grad med nadveren, kommer den direkte fra Gud ud af hans selvhengivende kærlighed, som begge hændelser er håndgribelige tegn på, selv om tegnets indhold, glæden, alene tages til hjerte, når det ord, der følger tegnet, kalder tilliden frem hos tilhøreren. Glæden er "Glæden i Helligaanden", uanset om den er "Herrens Himmel-Glæde", "Himmel-Glæden ved Herrens Bord", eller den er "Herrens Fødsels-Glæde".

\section{"Aande-Røst" som bærer af glæden}

Formuleringen "Glæden i Helligaanden", der forekommer i pinseprædikenen fra 1862, stammer fra Rom 14,17 og er på færde også i "Midt iblandt os er Guds rige" i str. 2 og str. 5-6. Skriftstedet kaster lys over, hvordan "Engle-Røst", 1853, kan blive til "Aande-Røst", 1864. Det sker ved, at den himmelske røst som kærlighedens stemme knyttes til pinsen. Både nadveren og kærligheden som element i denne højtids kendetegn har bibelsk forankring $\mathrm{i}$ hvert fald to steder.

Det ene er $\mathrm{i}$ afslutningen på fortællingen om pinsedag (ApG 2,4247), hvor kærligheden viser sig i beskrivelsen af den gensidige hjælpsomhed og i den glæde, der tilskrives den første menighed. Forbindelsen til nadveren markeres af bemærkningen: "hjemme i husene brød de brødet (...)" (ApG 2,46), der kan ses som henvisning til nadverindstiftelsen (Luk 22,19), og til den Opstandnes selvafsløring i Emmaus (Luk 24,30-31).

Det andet sted er i afsnittet om "Talsmanden, Helligånden, som Faderen vil sende i mit navn" (Joh 14,15-31). Her tolkes Joh 13,34: "Et nyt bud giver jeg jer: I skal elske hinanden. Som jeg har elsket jer, skal også I elske hinanden", på den måde, at opfyldelsen af dette nye bud forbindes med Talsmandens komme. ${ }^{25}$ Tilknytningen til nadveren fremgår af, at ordene falder under det sidste måltid, Jesus spiser sammen med sine disciple (Joh 13,1-30), hvor både forpligtelsen til gensidig tjeneste og forræderiets virkelighed er indarbejdet $i$ beskrivelsen af måltidet. Den inkarneredes udsathed er stadig til stede.

Ud over forkyndelse/dåb/nadver, tro/håb/kærlighed og retfærdighed/fred/glæde nævner pinseprædikenen fra 1862 også en fjerde treklang, nemlig jul/påske/pinse, som dog må "nøjes med at kaldes de smaa Højtider”. De tre store er den første treklang (HGS III, 172). På den måde opstår kæden nadver/kærlighed/glæde/pinse, hvor glæden må ses som "Glæden i Helligaanden", "Himmel-Glæden ved Herrens Bord", og tænkes båret af "Aandens Røst", sådan som "Herrens Fødsels-Glæde", glæden for hele folket, fremføres af en engel, med "Engle-Røst" (Luk 2,10). 
"Himmel-Glæden ved Herrens Bord" som knyttet til pinsen mødte vi i "Apostlerne sad i Jerusalem", 1839-43 (GSV II, str. 3, 263), og motivet med pinsen som en fest knyttet til kærligheden finder vi i strofen fra 1837:

Om Julen synger Troen bedst

Med Engle-Toner søde,

Mens Haabet har sin høie Fest

I Paaske-Morgenrøde,

Og Kicerlighed i Bølge-Gang

Sig fryder høit med Pindse-Sang,

Naar vore Tunger gløde!

(GSV I, str. 13, 231)

Her er "Pindse-Sang" en klar parallel både til strofens "Engle-Toner" ved juletid og gennem de glødende tunger til den "Aande-Røst", vi i 1864 træffer i "Midt iblandt os (...)". Da strofen fra 1837 blev optaget $i$ Festsalmer, 5. oplag, 1853, forsvandt både glæden, der gemmer sig i "sig fryder høit", og sangen selv sammen med det umiddelbart lidt dunkle udtryk "Kicerlighed i Bølge-Gang". ${ }^{26}$ I stedet kom det mere glatte "Og Kiærligheden klar og mild, / Den er vort Hjertes Pindse-Ild" (GSV IV, str. 7, 335).

Både glæde, sang og kærlighed tog imidlertid kraftig revanche med "I al sin Glands nu straaler Solen", 1843 og 1853 (GSV III, 514515; VI/2, 267-268), der blev offentliggjort netop i Festsalmer, 5. oplag. Uden brug af glosen bruser glæden gennem hele salmen. Takkesangen, der dukker op med "Fredskovens Nattergale" i str. 2 og vokser med "Menighedens fulde Kor" i str. 5, når sit højdepunkt i "Det evige Halleluja" i str. 6. Kærligheden står i fuldt flor med rosen i str. 7:

Vor Gud og Fader uden Lige!

Da blomstrer Rosen i dit Rige, (...)

Også i denne salme er der en tilbagekobling til julen. Den er direkte i linjen "I Ordets Navn, som her blev Kiød" (str. 4) og fremgår derudover af motivfællesskabet med "Velkommen igien, Guds Engle smaa", 1825 (GSV I, 405-406). ${ }^{27}$

Sammenhængen mellem forkyndelse, kærlighed, glæde og pinse i kombination med nadveren møder vi i salmen "Lyksaligt det Folk (...)", 1852-53, i strofen:

Lyksalig den Tunge i Menneske-Mund,

Med Liv og Røst,

Som slaaer sine Rødder i hjertelig Grund

Til evig Trøst,

Som skinner af Lyset i Livets Ord,

Som gløder af Ilden paa Naadens Bord,

Og skiænker de Hjerter, som græde 
Guds Fred og den himmelske Glæde!

(GSV IV, str. 4, 352)

I den foregående strofe er det hjertet, "Som liflig bevæges ved Himmelens Røst / Og Aandens Raab". Betegnelsen "Aande-Røst" for forkyndelsen, også ved nadveren, "Naadens Bord", ligger på den baggrund ligefor. Kærligheden er indlejret i strofen i linjen "Til evig Trøst" og i gavmildheden mod de grædende. Glæden nævnes direkte, og pinsen fremgår af, at mennesketungen "skinner" og "gløder" som ildtungerne i ApG 2,3. ${ }^{28}$

I den ovenfor omtalte pinseprædiken fra 1862 står sammenhængen nadver/kærlighed/glæde fast, selv om sangen som glædens udtrykkelige manifestation ikke er nævnt. Forskydningen i prædikenen fra vægt på de små, selvgjorte højtider, herunder julen, til fremhævelse af de store højtider, herunder nadveren, der i hvert fald i salmerne har pinsens verdensåbne karakter, kan være medvirkende årsag til udskiftningen af det kirkeårsprægede "Herrens Fødsels-Glæde" og "EngleRøst" med det umiddelbart mindre tidsbestemte "Himmel-Glæde" og "Aande-Røst".

\section{Sammenfatning}

Frelserens fødsel meddeles gennem "Engle-Sang". Som følgevirkning har den hyrdernes lovprisning. Med sin integration af taknemmelighed og viderebringelse af meddelelsen er den tegn på "Herrens FødselsGlæde". Frelserens nutidige nærvær i nadveren bæres af "AandeRøst", det ord, som høres i tro. Det besvares og bæres videre i salmesangens udtryk for taknemmelighed, "Herrens Himmel-Glæde". Det fælles i de to henvendelser fra det guddommelige består i, at Gud i Jesu menneskeliv afslører sin vilje til at stå last og brast med sin skabning, også når modgang trænger sig på, fejlgreb forekommer, og følgevirkningerne indbefatter døden.

Hver for sig lader de to formuleringer af henvendelsen og den måde, den meddeler sig på, sig forstå som udtryk for Guds Riges nærvær, når det ord, der samtidig lyder, høres som personlig henvendelse og opfordring og besvares med tillid og den taknemmelighed, som er glædens udtryk. Fællesnævneren for "Engle-Sang" og "AandeRøst", henholdsvis "Fødsels-Glæde" og "Himmel-Glæde", bliver på den baggrund inkarnationen forstået som en hændelse i historien, der stadig på ny udfordrer og opmuntrer, trøster og befrier mennesker.

Den glæde, sangen sætter i værk, rummer en ambivalens, fordi den lever i spændingsfeltet mellem risikoen for, at blive låst inde i en menneskelig højtid, som vender blikket bagud, og fristelsen til at flytte den uden for vores jordiske vilkår. Med "Fødsels-Glæde" som menneskeligt korrelat til "Engle-Sang" søges himmelflugten til en over- 
jordisk sfære afværget. Med "Himmel-Glæden" og dens udefra kommende korrelat "Aande-Røst" tages der afstand fra det menneskeligt selvberoende. De to formuleringer kan ses som udtryk for, hvilken fejlhøring Grundtvig på det givne tidspunkt har opfattet som mest nærliggende og derfor mest faretruende. Rettelsen fra den første til den sidste svarer til hans skepsis over for "de smaa Højtider".

\section{Konklusion}

Sangmotivet hos Grundtvig har flere steder den funktion, at det henviser til og fremhæver inkarnationen, det radikale indgreb og vedvarende omsving i den fælles, menneskelige tilværelse, der ifølge den kristne tro indtræder med Jesus af Nazareth og forstås som iværksat den eksterne instans, Israels folk dyrkede (Gud).

Motivet fungerer på samme måde i "Blomstre som en RosenGaard", men medtagelsen af det i str. 12 ved tekstændringen i 1868 medfører, at digteren nu ikke kun inddrager sit skelsættende erfaringsforløb i 1810-11, men også dets indvirkning på dansk menighedsliv, specifikt salmesangens udvikling, som integrerede følgevirkninger af inkarnationen. Offentlighedsaspektet i motivet kan således ses som medvirkende årsag til tekstændringen.

"Midt iblandt os er Guds Rige" er antagelig konciperet som salme til brug ved søndagsgudstjenester og således fra begyndelsen set i sammenhæng med det fælles menneske- og menighedsliv. Ændringen af ordvalg til motivet kan ses som udtryk for digterens bevidsthed om, at den menneskelige tilbøjelighed til at annektere omsvinget som selveje og skyde indgrebet fra Gud i baggrunden kræver, at det ordvalg, omsvinget udtrykkes med, så vidt muligt må modsige denne tilbøjelighed. I det givne tilfælde kan den skaffe sig tilhold ved overbetoning af julen som socialt afgrænset familie- og solhvervsfest og nedtoning af den som højtid for inkarnationens varige og verdensåbne hændelse. Da nadveren, som sættes i stedet, hos Grundtvig er knyttet til pinsen, der åbner inkarnationen mod alle jordens folk, må denne ændring betragtes som middel til at mindske risikoen for, at gudstjenesten i praksis bliver den lokale menigheds lukkede selvfejring. På den baggrund fastholder den nye formulering ikke kun glædens eksterne oprindelse, men prøver også at bevare dens verdensåbne hensigt. Igen synes offentlighedsaspektet at have haft betydning som medvirkende årsag til tekstændringen. 
Forkortelser

\section{Tekstsamlinger}

AO 1740: Biblia. Det er den ganske Hellige Skrifts Bøger (16. opl., 1819), København.

AO 1992: Bibelen. Den hellige skrifts kanoniske bøger, København.

BSS I-III: L. J. Koch (udg.) (1951-65), Hans Adolf Brorson. Samlede Skrifter, bind 1-3, København.

GSV I-VI: Th. Balslev et al. (udg.) (1944-66), Grundtvigs Sang-Vaerk, bind 1-6, København.

HGS I-III: Ernst J. Borup \& Frederik Schrøder (red.) (1929-31), Haandbog i N. F. S. Grundtvigs Skrifter, bind 1-3, København.

KSS I-VII: Hans Brix et al. (udg.) (1975) (genoptryk af 1939-1974 udgaven), Thomas Kingo. Samlede Skrifter, bind 1-7, København.

LXX: Alfred Rahlfs (udg.) (1952), Septuaginta, id est Vetus Testamentum Graece iuxta LXX interpres, Stuttgart.

MR: Oslo katolske bispedømme (udg.) (1961), Messeboken - Missale Romanum, Oslo.

US I-X: Holger Begtrup (udg.) (1904-09), Nik. Fred. Sev. Grundtvigs Udvalgte Skrifter, bind 1-10, København.

WA 35: W. Lucke (udg.) (1923), D. Martin Luthers Werke. Kritische Gesamtausgabe, 35. Band. Die Lieder Luthers, Weimar.

\section{Salme- og Sangbøger}

Boisen: P. O. Boisen (udg.) (1853), Bibelhistoriske Psalmer og Sange for Skolen, København.

DDS 53: Den danske Salmebog (1953), København.

DDS 03: Den danske Salmebog (2003), København.

ETF: P. A. Fenger (udg.) (1857 m. fl. opl.), Tillaeg til evangeliskchristelig Psalmebog, København.

F: N. F. S. Grundtvig (udg.) (1850 m. fl. opl.), Fest-Salmer, København.

FA: Salmebog, samlet og udgivet af flere Valgmenigheder (1918), Århus.

FHS: Folkehøjskolen Sangbog (1940.1984, 2006), Odense.

Hagen: A. C. Hagen (udg.) (1832 m. fl. opl.), Historiske psalmer og Riim til Børneloerdom, København.

KH: Psalmebog for Kirke og Hjem (1897 m. fl. opl.), København.

RT: Tilloeg til Psalmebog for Kirke- og Huus-Andagt, (1873), København.

SST: 46 Salmer. Tilloeg til Den danske Salmebog (1976), København. 


\section{Håndbøger}

AM I-V: Anders Malling (1962-66), Dansk Salmehistorie. Salmerne, bind 1-5, København.

$C B$ : C. Berg (1864), Grcesk-Dansk Ordbog, København.

HB: Holger Bennike (1970), Salmeordbog, København.

NTL III: Ragnar Askmark et al. (red.) (1957), Nordisk teologisk leksikon, bind 3, København og Lund.

ODS: Det danske Sprog- og Litteraturselskab (udg.) (2005-7), Ordbog over det danske Sprog, ODS på nettet, www.ordnet.dk.

WB: Walther Bauer (1937), Wörterbuch zum Neuen Testament, Leipzig.

WG: Walter Grundmann (1971), Das Evangelium nach Lukas, Theologischer Handkommentar zum Neuen Testament, bind 3, Berlin.

\section{Litteraturliste}

\section{Varker af Grundtvig}

Balslev, Th. et al. (udg.) (1944-66), Grundtvigs Sang-Vark, bind 1-6, København.

Begtrup, Holger (udg.) (1904-09), Nik. Fred. Sev. Grundtvigs Udvalgte Skrifter, bind 1-10, København.

Borup, Ernst J. og Schrøder, Fr. (red.) (1929-31), Haandbog i N. F. S. Grundtvigs Skrifter, bind 1-3, København.

\section{Værker af andre forfattere}

Albeck, Gustav (1954), “'Strandbakken ved Egeløkke' og 'Havet”, Grundtvig-Studier 1954, København, 22-39.

Andersen, Benny (1981). "Det er forår, Alting klippes ned", Oven visse vande, København. Også FHS, 285.

Auken, Sune (2005), "Herrens stridsmand i København", Sagas spejl. Mytologi, historie og kristendom hos N. F. S. Grundtvig, København, 182-209.

Balslev-Clausen, Peter (1983), "Du, som går ud fra den levende Gud", Grundtvig-Studier 1983, 42-68.

(1991), Det vingede ord. Om N. F. S. Grundtvigs Salmedigtning, København.

Borup, Johan (1943), Grundtvig, København.

Brix, Hans et al. (udg.) (1975) (genoptryk af 1939-1974 udgaven), Thomas Kingo. Samlede Skrifter, bind 3 og 4, København.

Brorson, Hans Adolf (1732), "Mit hierte altid vanker" i BSS I, 32-35.

Christiansen, Henrik (2006), "En overvejelse over ordet ihukommelse (...)", Prasteforeningens Blad 2006/38, København, 741-744. 
Dam, Poul (1999), "Noget om Myterne omkring den Clausen'ske injuriesag og Grundtvigs censurperiodes afslutning", GrundtvigStudier 1999, København, 7-26.

Gelting-Hansen, Erik (1955), Nadvergang og Alterskranker, København.

Helweg, Lise (1977-78), "Til Glæde for Graad - Om V-strukturen i Grundtvigshåbssalme", Grundtvig-Studier 1977-78, København, 247-259.

Kingo, Thomas (1689), "Hvad er det for en Snekke" i KSS IV, 210212.

(1689), "Min Sool, min Lyst, min glæde" i KSS IV, 116-118.

Koch, Carl (1925), "Grundtvigs 'Nyaars-Morgen"”, IV, Grundtvigske Toner, København, 51-55.

Koch, Hal (1959), N. F. S. Grundtvig, 2. udg. København.

Koch, L. J. (udg.) (1951-65), Hans Adolf Brorson. Samlede Skrifter, bind 1-3, København.

Lindhardt, P. G. (1945), Den nordiske Kirkes Historie, København.

Lundgreen-Nielsen, Flemming (1980), "Konklusion", Det handlende ord. N. F. S. Grundtvigs digtning, litteraturkritik og poetik 17981819, København, 883-897.

Lucke W. (udg.) (1923), D. Martin Luthers Werke. Kritische Gesamtausgabe, 35. Band. Die Lieder Luthers, Weimar.

Michelsen, William (1956), "Planens sprængning", Den sœlsomme forvandling i N. F. S. Grundtvigs liv. Studier over tilblivelsen af Grundtvigs historiesyn, København, 84-87.

Rahlfs, Alfred (udg.) (1952), Septuaginta, id est Vetus Testamentum Graece iuxta LXX interpres, Stuttgart.

Stevns, Magnus (1940), "Nogle Naturbilleder fra Grundtvigs Salmer", Fra Grundtvigs Salmevarksted, København, 26-57.

Thodberg, Chr. (1989), Syn og Sang, København.

- (1998), "Grundtvig og Gammel Testamente - den danske Bibel eller Septuaginta?", Grundtvig-Studier 1998, København, 61-80.

\section{Noter}

I Balslev-Clausen 1991, 20-33, bringer en meget detaljeret gennemgang af salmens opbygning.

2 Balslev-Clausen 1983 analyserer salmen nærmere og giver en grundigere omtale af begrebet "Fortabelsens Æt". - Et sekulært, poetisk udtryk for erfaringen af forårs/forsommerfænomenets forvandlende kraft er variationen i omkvædet i Benny Andersen 1981: "Men når forårssolen skinner, / blir jeg ung! (står jeg op. / blir jeg varm! / blir jeg glad! / lever jeg!)" Thodberg 1989, $216 \mathrm{f}$. 
Det må erindres, at denne godhed andetsteds fra trods udtryksformens brug af almenmenneskelige erfaringer ikke må forveksles med det indviklede forhold af følelsesmæssige og fællesskabsbestemte forbindelser mellem mennesker, der også bærer navn af kærlighed. Der er stærke forbindelser mellem dem, men de er ikke identiske. Dertil er det sidste forhold alt for præget af ambivalens mellem biologiske behov og ideelle ønsker, mellem naturlig egennytte og udadvendt handlingstrang og meget mere. Grundtvig kendte denne ambivalente og komplicerede karakter af "den jordiske kærlighed" tilstrækkeligt godt både fra forholdet mellem børn og forældre og fra forholdet mellem kønnene til, at den i sig selv kunne være hans grundlag i livet og dermed over for døden. Den eksterne instans er ham en nødvendighed. Derom vidner blandt andet salmen: "Jeg veed en Blomst saa faur og fiin", 1843 (GSV III, 528-529). Den er beregnet til brug ved brudevielse (GSV VI/2, 271, sp.1). Str. 2 indledes med definitionen: "Den faure Blomst er Kicerlighed", og str. 3 siger tydeligt, at intet væsen kan leve længere end denne kærlighed, der er kommet udefra:

Den Blomst med sig fra Paradis

Tog Adam og tog Eve,

Og alle Fugle sang dens Priis,

Hver paa sin Viis,

Kan ei den overleve.

(GSV III, str. 3, 529)

Grundleddet i 1.5 må være både mennesker og fugle. Ingen af dem kan leve længere end "Den faure Blomst".

Det fremgår også af salmen, at "Den voxer vildt dog kun paa Jord" (str. 4), og skal den kunne gro hos og mellem mennesker, er der kun én vej:

Velsignelsen af Jesu Mund, Hvor barnlig den annammes,

Den skaber i en salig Stund

En Hjertegrund,

Hvor Blomsten kan opammes!

GSV III, str. 6, 529)

2. udgave af "Sang-Vaerk (...)" bringer formen:

Velsignelsen af Jesu Mund,

Hvor Kiærlighed er inde,

Omplanter i en salig Stund

Paa hellig Grund

Den Blomst hos Mand og Kvinde!

(GSV VI/2, sp. 1, 271)

Her er modtagelses- og vækstmotiverne i "annammes" og "opammes" opgivet til fordel for en pointering af, at godheden kommer andetsteds fra, og af en forfining af det poetiske udtryk. Den tydeligere henvisning til den rituelle handling gennem tekstændringen til "Paa hellig Grund" medfører derudover, at sag og form følges bedre ad. Igen et eksempel på 
Grundtvigs opmærksomhed over for den betydning, konteksten har for forståelsen af en tekst.

5 Thodberg 1998 påviser salmens afhængighed af $L X X$ og gør opmærksom på, at der kan drages sammenligning med den såkaldte V-struktur, som kendes fra andre af Grundtvigs salmer (Helweg 1977-78, 247-259). Ludwigs 1927, 83, benævner meget træffende de tre dele af digtets tredje afsnit "Mørketiden" (str. 10-11), "Morgenen" (str. 12) og "Dagen" (str. 13-15).

6 Koch 1925, 51-55, fører Grundtvigs tillid til en kristelig og folkelig fornyelse tilbage til årene 1823-24. "Det var på én Gang en Opdagelse af Menighed og Menigmand" (s. 54). Ludwigs 1927, 84-87, gør rede for den betydningsbredde, glosen Gylden-Aar rummer kristeligt og folkeligt. Lundgreen-Nielsen 1995 peger på forholdet til Den danske Guldalder og dermed på glosens berøring med Grundtvigs folkelige bestræbelser og hans almene håb for fremtiden.

7 Borup 1943, 24-29, og Koch 1959, 68-80, giver korte referater af forløbet. Michelsen 1956 og Auken 2005 rummer mere indholdsprægede overvejelser over dets betydning for Grundtvigs forfattervirksomhed som historiker. Om de litterære konsekvenser, se Lundgreen-Nielsen 1980, 383-390.

8 Hvor radikal nyorienteringen i 1810-11 var, viser sig blandt andet ved, at den gav anledning til en række filosofiske, historiske, samfundsrelaterede og pædagogiske gennemtænkninger med teologisk fortegn. Et væsentligt udvalg kan findes under titlerne Danne-Virke, 1816-19, Kirkens Gienmale, 1825, med opfølgende artikler frem til "Om den Clausenske Injurie-Sag", 1831 (US V, 356-364), og afsnittet "Universal-Historisk Vidskab" i Nordens Mythologi, 1832 (US V, 394-418). I sammenhængen her fremstår de som forudsætninger for, at Sang-Vark til den Danske Kirke (1836-37) kunne udtrykke sig i et billedsprog, som ikke mistede jordforbindelsen. Det rummer en så vældig vidde og indtrængende prægnans, at man inden for salmedigtningen i vores kulturkreds antagelig skal tilbage til selveste Davids Salmer for at finde noget tilsvarende.

9 Dam 1999, 11-12, regner afvisningen af salmebladet for muligt medvirkende årsag til, at Grundtvig nedlagde sit embede ved Vor Frelsers kirke.

10 I begyndelsen var Festsalmer særtryk til særlige anledninger. Fra og med 5. oplag, 1853, må samlingen betragtes som et egentligt tillæg med stadigt mere udtalt præg af selvstændig salmebog. Efter Grundtvigs død får bogen titlen N. F. S. Grundtvigs Kirke-Salmebog, således f. eks. 17. opl., 1889, og 23. opl., 1912. Senere genoptages den oprindelige titel, således i en "ændret og øget udgave" fra 1927. Derved dannes den yngste tråd i klassisk dansk salmetradition. Den ældste, kongerigets, med Hans Thomissøns Den danske Psalmebog, 1569, og Kingos Psalmebog, 1699, som de fornemste repræsentanter, blev midlertidigt, men alt for længe afbrudt af Evangelisk-Kristelig Psalmebog, 1798. Noget yngre er hertugdømmernes tradition med en repræsentant i Allgemeines Gesangbuch, 1780, en pendant til Guldbergs Salmebog, 1778, for kongeriget. Denne traditions seneste repræsentant er Den Sønderjydske 
Salmebog, 1925. Sammen danner de tre traditioner, der fra og med Den danske Salmebog, 1953, samles og udbygges med nyere stof, dansk salmesangs "tretvundne snor" (Præd 4,12).

11 Tyve års bestræbelser på at genoprette og forny den danske salmesang kan opregnes således:

\begin{tabular}{|c|c|c|}
\hline 1822 & B. S. Ingemann & Morgensalmer til Sorø Akademi \\
\hline 1825 & B. S. Ingemann & Højmessesalmer \\
\hline 1827 & P. A. Fenger (udg.) & $\begin{array}{l}\text { Psalmer og aandelige Sange af } \\
\text { Thomas Kingo }\end{array}$ \\
\hline 1830 & J. A. Holm (udg.) & Brorsons Psalmer og aandelige Sange \\
\hline 1831 & L. C. Müller (udg.) & Udvalg af Danske Psalmer \\
\hline $1832 \mathrm{ff}$. & L. C. Hagen (udg.) & Historiske Psalmer og Riim \\
\hline $1832 \mathrm{ff}$. & C. J. Boye & $\begin{array}{l}\text { Aandelige Digte og Sange (flere } \\
\text { hæfter) }\end{array}$ \\
\hline $1836-37$ & N. F. S. Grundtvig & Sang-Værk til den Danske Kirke \\
\hline 1837 & B. S. Ingemann & Morgensalmer for Børn \\
\hline 1838 & B. S. Ingemann & Syv Aftensange \\
\hline 1839-41 & N. F. S. Grundtvig & $\begin{array}{l}\text { Sang-Værk til den Danske Kirke- } \\
\text { Skole }\end{array}$ \\
\hline $1843 \mathrm{ff}$. & H. A. Timm & $\begin{array}{l}\text { Aandelige Sange. - Christelige Sange } \\
\text { (flere hæfter) }\end{array}$ \\
\hline
\end{tabular}

12 Den ringeste af disse ændringer må være den metriske omarbejdelse af "Paa Jerusalem det ny" ( $R$ 284; $A M$ IV 297), antagelig foretaget af hensyn til melodien, da Rungs først forelå i 1859. Denne 'Jerusalems forstyrrelse' må ses som en del af baggrunden for Grundtvigs mundtligt overleverede bemærkning: "Der maa være en Salmedigter til her i Landet, der hedder N. F. S. Grundtvig. Ja, jeg kjender ham ikke, men det maa være ham, der har fået Salmer optaget i Konvents-Salmebogen, af mig er de ikke" (AM IV 297, der henviser til Dansk Kirketidende, 1886, sp. 150; - med tak til Jette Holm for venlig hjælp til tekstlig lokalisering af en gammel læseerindring).

13 Thodberg 1998, 63, kalder salmebogsudgaven "amputeret", men noterer også, at bearbejdelsen er Grundtvigs egen. Der må vel også kunne argumenteres med, at selv en torso kan rumme stor skønhed. Tabet i eksistentiel intensitet hidrører især fra udeladelsen af det afsnit, Ludwigs 1927, 83, kalder "Mørketiden" (str. 11-12), mens udeladelsen af stroferne 2, 7 og 14 fratager salmen forfatterens prægnante, men i dette tilfælde særdeles særegent formulerede syn på en kirkelig tradition om Jordan som dåbens prototype. Se også Thodberg 1989, note 37, 119.

"Blomstre som en Rosen-Gaard" er i øvrigt som bekendt ikke det eneste eksempel på, at Grundtvig udtog strofer af et længere digt for at danne en salme. "Til klart Guds Ansigt vi skal see", 1837 (GSV I, 228230), der henviser til 1 Kor 13, og hvoraf to strofer omtales her på s. 132 og i noterne 25 og 26, ligner med sine 13 strofer og i sit anlæg et læredigt, men omstøbes ved optagelsen i Festsalmer, 5. opl., 1853 (GSV IV, 258-259), til regulær salmeform.

Nævnes kan også "For dig, o Herre, som Dage kun", 1857 (GSV V, 154), "O Kristelighed", 1853 (GSV IV, 346-47), og "Vidunderligst af alt 
paa Jord", 1853 (GSV II, 385-386), der er hentet i digtene "Moses i Ørken", 1839 (GSV II, 78-83), "Jeg kiender et Land", 1824 (GSV III, 145-148), og "Jeg er saa underfuld en Magt", 1829 (GSV I, 33-36).

14 Gennem en menneskealder havde også "Kammersvenden i Morland" regelmæssigt været på færde i kredsen omkring Grundtvig, ganske vist uden meditationsdelen og dens blomstermotiv, men dog med erindringsmulighed over for Es 35. Den blev medtaget i Hagen, hvis 6. udgave kom i 1856, og i Boisen, hvis 4. udgave kom i 1865.

15 I et litterært perspektiv ses en tilsvarende vurdering i Lundgreen-Nielsen $1980,897$.

16 Ordlyden fra 1864 går videre i $K H, D D S 53$ og valgmenighedernes salmebøger fra samme tidsrum. Også $F H S$ bruger denne form, så længe salmen medtages. $D D S 03$ vender tilbage til ordlyden fra 1853.

$17 C B 1864,1299$, sp. 1n-2.

$18 C B 1864$ og WB 1927 s.v. katályma og katalyå. WG 1971, 80-81.

19 Motivet "fremmed og gæst" udformes hos Grundtvig i 1837 gennem de tiggere (GSV I, str. 5, 384), der erstatter Brorsons betlere (BSS I, str. 7, $34)$, og i 1845 gennem modsætningen til spurven og svalen $(G S V \mathrm{VI} / 1$, sp. 1, 69), der er overført næsten ordret fra Brorson (BSS I, str. 9, 34). Gendigtningen fra $1845 \mathrm{kom}$ i brug i grundtvigske salmebøger og i FHS. Brorsons tekst ligger til grund for DDS 03125 .

20 Med udeladelse af str. 7, der ellers er salmens pointe, blev "Den Husvilde" optaget i $F A$, mens str. 1, 3, 5 og 7 gik over fra $S$ og $M F$ til $D D S 53$ og videre til DDS 03 som en efterhånden yndet salme til Laubs karakteristiske melodi.

21 Kraft er et af de udtryk, Grundtvig bruger, når Gud udøver sin gerning som Helligånd, ofte på en måde, så glosen er et dæknavn for dette aspekt i gudsbilledet. Flere af disse udtryk er samlet i slutstrofen fra treenighedssalmen "Alt staaer i Guds Faderhaand", 1856: "hans Liv og Fred, / Lys og Kraft og Herlighed / (...)" (GSV V, str. 3, 44).

22 I DDS 53426 kunne man endnu danne sig et indtryk af den rolle, både glædes- og modgangsmotivet spiller i salmen. Det sidste er faldet ud i den barsk forkortede DDS 03 467. Glædesmotivet er med i reduceret skikkelse i "fred og fryd" i str. 1 og i "barneglæden din" i str. 7.

23 Denne tolkning af 'minde' som aktiv primærfaktor støttes af Grundtvigs ordvalg i str. 1: "Frelser, i dit Venne-Lag / Mindet er en Hovedsag". Formen i DDS 03: "Frelser, i din menighed / skal dit minde vare ved", går tilbage til $R$, der også ændrede str. 3, 4-5, til: “ / mindet gløder i vort bryst, / har på tungen englerøst” ( $A M$ III 333-334). Begge steder er betydningen af 'minde' forskudt, så det objektive moment svækkes på bekostning af, at 'minde' også kan betegne vores subjektive erindring. Det er en svækkelse af tekstens hensigt. Festsalmer fastholder i Grundtvigs levetid formen fra 1837, idet dog "Hovedsag" ændres til "Hjertesag" i 1864 (GSV IV/1, 114). Se også note 12.

Christiansen 2006 omtaler en række filologiske, eksegetiske og liturgiske vurderinger af glosen anamnesis (Luk 22,19; 1 Kor 11,24.25) og dens forhold til det hebraiske zikkarôn (4 Mos 10,10). I vores forbindelse er det betydningsfuldt, at 'minde' eller 'ihukomme(lse)' set 
som en tidligere hændelse, der er fremtidsrettet tilskyndelse mere end fortidsforankret erindring, svarer til betydningen i 4 Mos og 1 Kor.

I $A O 1992$ understreges zikkarôns aktive aspekt i 4 Mos 1,10 ved oversættelsen: "På jeres glædes dag, jeres fester og jeres nymånedage skal i blæse i trompeterne (...); det skal bringe jer i erindring for jeres Gud (...)" (min kursivering). Her er det altså Gud, der har brug for en påmindelse (!). Regnbuen efter Syndfloden (1 Mos 9,14-17) har i øvrigt den samme funktion som trompeterne på "jeres glædes dag, (...)”. Her bruger den hebraiske tekst to gange verbet med samme rod som zikkarôn. $A O 1992$ oversætter reaktionen hos Gud, når pagtstegnet viser sig, med "husker jeg" og "vil (...) jeg huske (...) min pagt", mens $A O 1740$ har "ihukommelse" og "komme (...) i hu".

I 1 Kor 11,23-26 har selve udførelsen af nadverhandlingen: "at (...) I spiser brødet og drikker bægeret (...)," den virkning, at menigheden "forkynder Herrens død indtil han kommer", når udførelsen sker i overensstemmelse med, hvad Jesus sagde "i den nat, da han blev forrådt", altså, at det gøres til hans "ihukommelse". Altergangen har således samme opgave som trompetfanfarerne og regnbuens tilsynekomst, der er midler til at fastholde, at der gælder "en evig pagt for jer (...)" (4 Mos $10,8)$, og at der er "en evig pagt (...)" mellem Gud og "alt levende på jorden" (1 Mos 9,16).

En ligefrem brug af passagen fra 1 Kor har vi hos Petter Dass i slutstrofen til hans "Første Sang" om nadveren i hans Morten Luthers lille Catechismus, 1715:

Dit Minde skal, o Jesu! Staa

U-glemt i Sind og Tanker,

Mens Brøød af Ager er at faa,

Og Druer groor paa Ranker,

Og hvor der brydes hellig Brød

Der skal forkyndes Herrens Død

Blant unge Folk og gamle,

Indtil du siunlig kommer frem

I Skyen os at hente hiem,

Og i dit Riige samle.

(AM I 248. Jf. DDS 03 473)

Her har agerdyrkningen samme position over for forkyndelsen af "Herrens død / (...) Indtil du (...) kommer", som trompeterne og regnbuen har i forhold til fastholdelsens af den evige pagt. Nu er det naturligt nok ikke Gud, men os, der har brug for påmindelsen.

Der er klart en ensartethed i dynamikkens struktur hos Dass og hos Grundtvig i "Mindes vi (...)". Når der hos Dass “(...) brydes hellig Brød", "forkyndes Herrens Død / Blant unge Folk og gamle". Når vi hos Grundtvig "om dit Nadver-Bord / (...) tage Sæde", træder "Minde dit" i funktion, "Har paa Læben Engle-Røst". Hvorvidt Grundtvig har kendt Dass' katekismusviser, der foreligger i en udgave, som er trykt i København i 1794 ( $A M$ I 24), er uvist, men der er i hvert fald tale om velkendt, fælles stof og sikkert en konventionel tolkning, hvad angår den handlingsfremkaldende betydningsnuance i 'minde'. I dagligsproget 
forekommer den i forbindelse med verbet 'minde' i udtryk som: "Det minder mig i øvrigt om, at jeg skal besøge onkel Peter", og kendes i hvert fald i ældre sprogbrug også om substantivet.

$O D S$, s.v.'(II) Minde (4)', anfører betydningen: “ting (...), som har til formål at bevare erindringen, mindet (3)", hvor 'minde (3)' defineres: "En (enkelt) i hukommelsen bevaret forestilling om noget (...)". Blandt de anførte citater er de kendte ord fra Oehlenschlägers "Guldhornene": "I, som raver i blinde, / skal finde / Et ældgammelt Minde (...)" og de mindst lige så kendte fra Brorsons "Her vil ties, her vil bies": "Turtel-Due, kom at skue / (...) Bag Gierdet hist, / Der skal du finde Forsommers Minde (...)". I det sidste citat går betydningen i retning af 'påmindelse' snarere end 'bevaring af erindring'. Det forekommer relevant også i "Guldhornene", eftersom 'Mindet' misbruges i dette digt ved, at påmindelsen misforstås: "Men I see kun deres Lue, / ikke det ærværdigt Høie". Erindringen kan svinde eller svigte, men kun misbruges, når 'mindet' også er påmindelse.

'Påmindelsen' er også en opgave for 'mindesmærket', der anføres som parallel i $O D S$, en betydning, vi møder hos Grundtvig i hans omtale af de folkelige viser i Mands Minde. Her nævner han Frihedsstøtten som et af "de offentlige Mindesmærker, som virkelig minde Folket om noget godt (...)". Han taler tilmed om, "at Aften-Lærken vil flokkevis opsvinge sig fra den og slaa Himlen et godt Stykke nærmere" (HGS II, 85). Frihedsstøtten som mindesmærke fremkalder altså den folkelige sang på samme måde, som altergangen i sin egenskab af "Minde dit" udløser "Engle-Røst".

I skikkelse af parallelle udtryk i to julesalmer og to pinsesalmer kommer en tilsvarende ensartethed mellem Frelserens fødsel og Helligåndens komme med tilblivelse af den menighed, hvor nadveren fejres, også frem. Vi møder "Men giæstet I har en Hytte før" (GSV I, str. 3, 405) fra "Velkommen igien, Guds Engle smaa" over for "Reis afby og giæst vor Hytte" (GSV I, str. 2, 597) fra "Sidder rolig i Jerusalem" og "O, vær velkommen, ædle Giæst!" (GSV I, str. 9, 349) fra "Fra Himlen høit kom jeg nu her" over for "Hjerte-Kamrets ædle Giæst! / Vær hos os tilstæde (...)" (GSV I, str. 2, 611) fra "Kom, o Hellig-Aand, kom brat!".

$M R, 548-549$, bruger Joh 14,15-21, som tekst pinseaften. Hos os er denne tekst siden indførelsen i 1885 af 2 . tekstrække kommet i brug som evangelielæsning til pinsedag ( $D D S$ 03, s. 1173), mens Joh 14,22-31, er evangelielæsning efter første tekstrække.

Også middelalderantifonen, antagelig fra 1000-tallet, med de tre indledende linjer: Veni sancte spiritus / reple tuorum corda fidelium / et tui amoris in eis ignus accende (Kom, Helligånd / fyld på ny dine troendes hjerter / og antænd din kærligheds ild i dem (min overs.)), må nævnes i sammenhængen. Den er især knyttet til pinsetiden ( $A M$ II, 50). De tre citerede linjer har meget stof til fælles med str. 3 i Martin Luthers "Nun bitten wir den heyligen Geyst":

Du susse lieb, schenk uns deyne gunst,

las uns empfangen der liebe brunst,

Das wyr uns von hertzen ein ander lieben 
Und ym friede auf eynem synn blieben.

Kyrieleis.

(Du søde kærlighed, giv os din bevågenhed, / lad os modtage kærlighedens glød, / så vi elsker hinanden af hjertet / og holder fred med et enigt sind (min overs.).

Tekst $W A, 447-448$, her efter $A M$ III, 421).

Grundtvig oversatte i 1837 både antifonen, som han kalder "det berømte Latinske Vers (...)" (GSV I, 264), og Luthers salme (GSV I, 95-96). Da han i 1845 vendte tilbage til denne salme, lod han str. 3 begynde: "Du Kiærlighedens Ild, indgyd / Os Helgenlivets søde Himmelfryd" (GSV IV, 161). Både kendskab til og udtryk for kærligheden som kendetegn for pinsen er således åbenlyse. Det er tydeligt gamle stier, Grundtvig betræder, og givetvis ganske bevidst, når han knytter pinse, Helligånd og kærlighed sammen.

Udtrykket "Kiærlighed i Bølge-Gang" kunne henvise til, at menneskenes liv og dermed også deres kærligheds vilkår er en urolig og ofte uigennemskuelig affære. Det viser sig dels $i$, at billedet af livet som en sejlads har en lang tradition i europæisk digtning, dels bruger Grundtvig selv gerne billedet af havet om menneskeslægtens livsløb, "fordi det afspejler Tidernes Færd og i sin Vekslen mellem Storm og Stille taler saa kløgtigt til Sindet" (parafrase i Albeck 1954, 33).

En anden, dermed sammenhængende, men mere præcis begrundelse for talen om "Kicerlighed i Bølge-Gang" synes mig at være fortællingerne om stormen på søen (Matt 8,23-27 par.) og om vandringen på søen (Matt 14,23-34 par). Uanset de irrationelle elementer, disse fortællinger rummer, lader de sig såre enkelt se som forkyndelse af den inkarneredes nærvær hos og betydning for mennesker, der omtumles af livets storme.

Den bibelske baggrund for billeddannelsen bestyrkes af henvisningen til 1 Kor 13 i en note til formen fra 1837, hvor str. 1 lyder:

Til klart Guds Ansigt vi skal see,

Og ret Hans Hjerte kiende,

Paa Jorden, som i Himlen, Tre

Guds Gierninger fuldende,

I Naade kom de ovenned,

Og Tro og Haab og Kicrlighed

Er Navnet paa de Trende.

(GSV I, str.1, 228)

\section{Festsalmer, 5. opl., 1853 er ordlyden:}

Til klart Guds Aasyn vi skal see

Og ret Hans Hjerte kiende,

Guds Gierning hos os Dyder tre

Begynde og fuldende,

Med Aanden kom de ovenned,

Og Tro og Haab og Kiærlighed

Er Navnet paa de Trende.

(GSV IV, str. 1, 334)

I Festsalmer, 8. opl., 1864 (GSV VI/2, sp. 2, 333) rettes "Med Aanden" til "Med Christus", og den form går som den mest billeddannende og 
vægtige videre i salmebøgerne. "Tre", subsidiært "Dyder tre", nemlig tro, håb og kærlighed, gennemfører "Guds Gierning(er)". Er det et underfundigt spil med den græske mytologis tre gratier "med dyden i midten'? I Grundtvigs strofe er kærligheden tydeligvis ét af tre næsten personale værktøjer, en delfunktion i inkarnationens dynamik og ikke en isoleret human aktivitet. "Pindse-Sang" i str. 13 er derfor også udtryk inkarnationens indvirken på menneskelivet, sådan som disciplenes knæfald i Matt 14,33, troens julesang og salmesangen ved nadveren er det. Netop i 1837, da udtrykket "Kicerlighed i Bølge-Gang" danner sig i digterens sind, har Grundtvig haft fat i den af ham højt agtede Thomas Kingos salme til 3. juledag: "Min Sool, min Lyst, min glæde", 1689 (KSS IV, 116-118), hvor vi møder linjerne: "Mand siger, at Dig følger / Kun Korss og Kummer med / Og at mand gaar i Bølger, / I dine Fode-fied! (...)" (KSS IV, str. 4, 117). Det er en klar hentydning til episoden, hvor Peter træder ud på bølgerne til Jesus (Matt 14,28-32). Grundtvig gengiver: "Man siger, Kors dig følger, / Med al Elendighed, / I Modgangs dybe Bølger / Er dine Fode-Fjed (...)" (GSV I, str. 4, 377), og så tilføjer han uden belæg hos forgængeren denne slutstrofe:

Imens Du da er lille, Lad saa os blande Blod,

At ei os kan adskille

Selv Helveds Lue-Flod!

Da skal i Himmerig,

Med Aands og Hjertes Glæde,

Jeg Jule-Psalmer kvæde

For Fader og for Dig!

(GSV I, str. 8, 378-379)

Også her går kærligheden hen over bølgernes urolige gulv, endda hvor de i skikkelse af "Helveds Lue-Flod" er allermest dødbringende.

Kærlighedens menneskelige modtager i digterens skikkelse fremfører sit ønske om total forening med den nyfødte, hvis jordiske skæbne forud er omtalt som den rene elendighed. Foreningen formes med den gamle forestilling om vennerne, der indgår en livsvarig pagt ved at blande blod, men bagved mere end aner man ordene om "kalken efter aftensmåltidet": "Dette bæger er den nye pagt ved mit blod (...)" (1 Kor 11,25 par). Derfor lader nadverritualets tilstedeværelse i tankegangen sig næppe udelukke, og takkesangen for det fællesskab, der bærer igennem selv de dybeste eksistentielle trusler, benævnes ligeud "Jule-Psalmer", naturligvis fordi salmen hos Kingo er henlagt til 3. juledag.

Nogle få år før, i 1832, skrev Grundtvig en (i øvrigt ikke særligt god) bibelhistorisk sang (GSV III, 187-189) med første linje hentet fra Kingos evangeliesalme om stormen på søen: "Hvad er det for en Snekke", 1689 (KSS IV, 210-212). Også her markerer Grundtvig eksistensen af takkesangen, endda to gange, og igen uden belæg hos Kingo. Den sidste strofe lyder:

Da raabe Mark og Fjeld:

Kom, lad os Herren love, 
Som over Vind og Vove

Har Magt i Gry og Kveld!

(GSV III, str. 7, 189)

Sammenhængen mellem den inkarneredes selvhengivende kærlighed og sangen forekommer i de to tekster under forhold, som uden vanskeligheder lader sig betegne som "Bølge-Gang". Når det kan lade sig gøre i forbindelse med julen og med menighedens almindelige skæbne, kan vejen også stå åben til, at "Kicerlighed i Bølge-Gang / Sig fryder høit med Pindse-Sang". At skibet bruges som metafor for kirken, og at denne ifølge traditionen fejrer fødselsdag i pinsen, kan være en medvirkende associationskanal ved billeddannelsen.

Stevns 1940, 48-53, bringer en koncentreret sammenstilling af julesalmen "Velkommen igien, Guds Engle smaa", 1824 (GSV I, 405-406), med påskesalmen "Verdens Igienfødelse", 1837 (GSV I, 462-463), og pinsesalmen "I al sin Glands nu straaler Solen", 1853 (GSV VI/2, 268). Sammenstillingen er oplæg til en gennemgang og vurdering af naturbillederne i "Den signede Dag med Fryd vi see", 1826 (GSV III, 161-164). Det påvises, at naturbillederne hos Grundtvig ikke "er medtaget til Forhøjelse af et Skønhedsindtryk - tværtimod. Vægten ligger paa den sindbilledlige Værdi" (Stevns 1940, 26). Som eksempler nævnes, at "Solen" staar op ved Midnatstid (...)" og "Vaaren" blomstrer i Sne og Kulde (...)" (s. 52)

Den "Bølge-Gang", der er Guds kærligheds vilkår i verden og den menneskelige kærligheds særpræg, er af samme art som de andre naturbilleder. På grund af sine ferierejser fra Thyregod i barndommen og sine Englandsrejser senere i livet havde Grundtvig vel nok færdedes mere til søs end de fleste af sine landsmænd. Derfor har han også kendt til, at en skude kan gynge mere, end betryggeligt er. Alligevel er det hverken den vigtigste eller den eneste adgang til billeddannelsen. Det bibelske motiv og den litterære tradition, der er omtalt i note 26 , arbejder sammen med digterens egen erfaring. De støtter hinanden og giver motivets udformning sproglig spændstighed. Resultatet er i tilfældet "Kicerlighed i BølgeGang / Sig fryde høit med Pindse-Sang, / Naar vore Tunger gløde!" en kompliceret metafor, der nok på sin vis er hverdagsnær, men med sine krav til særlige forudsætninger hos læseren er også svært tilgængelig.

Formen i Festsalmer, 5. opl., er mere ligefrem og kan høres som et ekko af bønnen til Helligånden i linjerne: "Os forlene deilig Røst, / Os opgløde dybt i Bryst, / Dine Flammer rene!" fra den oversatte pinsesekvens "Kiærligheds og Sandheds Aand!", 1837 (GSV I, str.1, 612). Den lyder: "Og Kiærligheden klar og mild, / Den er vort Hjertes Pindse-Ild, / Naar vore Tunger gløde!” (GSV IV, str. 7, 335) og kan måske ses som et eksempel på, at Grundtvig følger sin egen anvisning om, hvordan man gør sin indflydelse gældende:

O, mærker dog, Blinde!

Hvad Tosser forstaae:

Hvo Marken vil vinde,

Maa prøve derpaa!

Hvo Folket vil træffe 
Tilbunds under Øe,

Med Folket maae bjæffe,

Om ei det kan gjøe!

Hvo for det vil sjunge,

Maa laane dets Tunge,

Og lare at aande paa den!

("Nyaars-Morgen", str. 198. US IV 309;

Grundtvigs fremhævelser)

Her viser de fremhævede slutlinjer, at det ikke handler om at hyle med de ulve, man er iblandt, eller tale folk efter munden, men om at udtrykke sine egne tanker på en måde, der tager hensyn til tilhørernes dagligsprog. Om dette så altid er lykkedes for Grundtvig selv, lader sig nok diskutere.

Salmens første strofe:

Lyksaligt det Folk, som har Øre for Klang

Herovenfra!

Det nynner alt her paa den evige Sang:

Halleluja.

Saa alle Guds Engle forundres paa,

Hvor himmelsk de jordiske Klokker slaae,

Naar Aanden med Støvhjertets Tunger

Dets dybeste Længsel udsjunger!

(GSV IV, str. 1, 351)

er i øvrigt et fint eksempel på kombinationen af vekselvirkningen mellem englesang/menighedens sang og motivet kirkeklokkernes ringen/kimen, se afsnittet "Den livgivende Ånd" (ovenfor, s. 109).

29 Selv om Grundtvig synger om den glæde, der som glæde fra Gud altid er nær, frit bevægelig og ikke bundet til en adresse i Løngangsstræde i København, hindrede det ikke en vis tendens til at se "dit (Guds) Vennelag" (GSV I, str. 8, 615) som "vort (Vartovmenighedens) Vennelag", så gæstfriheden ved Herrens bord kunne komme i vanskeligheder. Det slog ud i lys lue, da Morten Pontoppidan blev nægtet deltagelse i nadveren i Vartov (NTL III, 96). På den anden side blev åbenheden i nadversynet baggrund for, at valgmenigheden på Mors omdannedes til frimenighed, fordi dens præst, Rasmus Lund, insisterede på muligheden for, at børn kunne gå til alters inden konfirmationen (Lindhardt 1945, 234). Et sympatisk forsvar for børnealtergang ud fra et grundtvigsk syn er Gelting-Hansen 1955. 